\title{
[総合論文］
}

\section{H-モルデナイト触媒による多環芳香族炭化水素の 形状選択的アルキル化反応}

\author{
杉 義弘 ${ }^{\dagger 1) *}$, 花岡 隆昌 ${ }^{\dagger 2}$ \\ †1) 岐阜大学工学部応用精密化学科, 501-1193 岐阜市柳戸 1-1 \\ †2) 物質工学工業技術研究所機能表面化学部, 305-8565 茨城県つくば市東 1-1
}

(平成 9 年 11 月 19 日受理)

\begin{abstract}
多環芳香族炭化水素のアルキル化反応におけるゼオライト触媒の形状選択性を検討した。ビフェニルおよびナフ夕 レンのイソプロピル化においては，H-モルデナイト（HM）のみが形状選択性を示し，立体的に最も小さい 4,4'-ジイ ソプロピルビフェニル (4,4'-DIPB)，2,6-ジイソプロピルナフタレン（2,6-DIPN）を選択的に生成した。これらの選 択性は, 反応が空孔内において進行し, 空孔, 基質および触媒活性点からなる遷移状態における立体的相互作用によ り発現する。この際, 触媒活性および形状選択性は, 固体酸点における炭素質生成の程度に支配される。すなわち, $\mathrm{SiO}_{2} / \mathrm{Al}_{2} \mathrm{O}_{3}$ 比の低い $\mathrm{HM}$ では, 炭素質生成による空孔閉そくおよび外表面酸点における非選択的反応のために, 触媒 活性および4,4'-DIPBまたは 2,6-DIPN選択性は低くなる。しかし, $\mathrm{SiO}_{2} / \mathrm{Al}_{2} \mathrm{O}_{3}$ 比の高い脱アルミニゥム $\mathrm{HM}$ では, 炭 素質生成が起こりにくいので, 触媒活性が飛躍的に向上し，4,4'-DIPB および 2,6-DIPN の選択率がそれぞれ最高 $90 \%$ および $65 \%$ に達した。

ビフェニルのイソプロピル化において，4,4’-DIPB 選択率はプロピレン圧により支配される。0.3 MPa 以上では, 反応中の 4,4'-DIPB 選択率は一定であるが, 0.2 MPa 以下の低圧では 4,4'-DIPB から 3,4'-DIPB への異性化が起こるた めに, 反応の進行とともに 4,4'-DIPB 選択性が低下する。この際, 触媒に包接された DIPB 異性体中の 4,4'-DIPB 選 択率は圧力にかかわらずほほ一定であることから，この異性化反応は外表面酸点で進行すると考えられる。

ビフェニルのエチル化においては，イソプロピル化と異なり，4,4'-ジエチルビフェニル (4,4'-DEBP) の選択率は 低い。また，4,4'-DIPB のイソプロピル化は高プロピレン圧下でも進行しないが，立体的に小さい 4,4'-DEBP は他の 異性体に比べて優先的にエチル化されるので，ポリエチルビフェニル（PEBP）を生成する。この反応性の差は HM 空孔内での遷移状態規制の差に基づくものである。

外表面酸点を不活性化することにより非形状選択的アルキル化反応および異性化反応を抑制するために，HMのセ リウム修飾を試みた。セリウム修飾後，550年で焼成することにより，HM 空孔の閉そくなしに表面酸点が不活性化 された。本触媒をナフタレンおよびビフェニルのイソプロピル化に適用したところ，外表面におけるアルキル化およ び異性化反応を効率的に抑制され，2,6-DIPN および4,4'-DIPB の選択率が向上した。
\end{abstract}

\section{1.はじめに}

ゼオライトは，不均一系触媒の分野で基礎から応用まで広い 範囲の研究対象として古くから用いられてきた1) 5)。これは, ゼオライトが，それ自身の機能を生かした固体酸・塩基触媒ば かりでなく，金属担持触媒，担持金属イオン触媒等の担体とし ても高い機能を有すること，またその構造が明確であり，活性 点構造, 作用機構等の解明および触媒設計を行う上で優れた材 料であることに基づく。また，ゼオライトの持つ微空間は有機 分子の大きさとほほ対応することから，目的生成物を選択的に 合成するために，その分子認識能を利用する試みが古くから行 われてきた。

ビフェニル等の多環芳香族化合物は, 剛直性, 光反応性等, 優れた分子物性を有することより，高機能性材料の鍵化合物と して注目されている。多環芳香族化合物を材料として利用する ためには，まず官能基を特定位置に選択的に導入する必要があ る。この目的を達成するために多くの反応が検討されており，

\section{* 連絡先}

形状選択的アルキル化反応は有力な方法の一つである ${ }^{4), 6)}$ 。芳 香族化合物のアルキル化反応は, 固体酸を触媒とすると円滑に 進行するが, 基質および触媒の種類によりアルキル化の程度お よび異性体分布に大きな差が生じる。機能性材料前駆体として 価值の高い 4,4'-ジアルキルビフェニル，2,6-ジアルキルナフ夕 レン等の対称性の高い誘導体を効率的に合成するには, ゼオラ イトが有する規則的な空孔内で反応を行うなどの反応場の立体 規制が必要である。

著者らは, 過去数年にわたりゼオライト触媒による多環芳香 族炭化水素の形状選択的アルキル化に関する研究を行ってき た4),6) 28)。ここでは, ビフェニルおよびナフタレンのアルキル 化における有効なH-モルデナイト（HM）の触媒活性および形 状選択性についてまとめた。

\section{2. ゼオライト触媒を用いる形状選択的触媒反応}

ゼオライトは, 結晶性のアルミノケイ酸塩の総称であり, $\mathrm{SiO}_{2}$ の 4 面体構造を基本とする多くの結晶形態が存在する。 これらのゼオライトは結晶学的に決定される特有の空孔構造を 有し, 各種の有機化合物の分子直径に近い空孔が結晶表面に開 

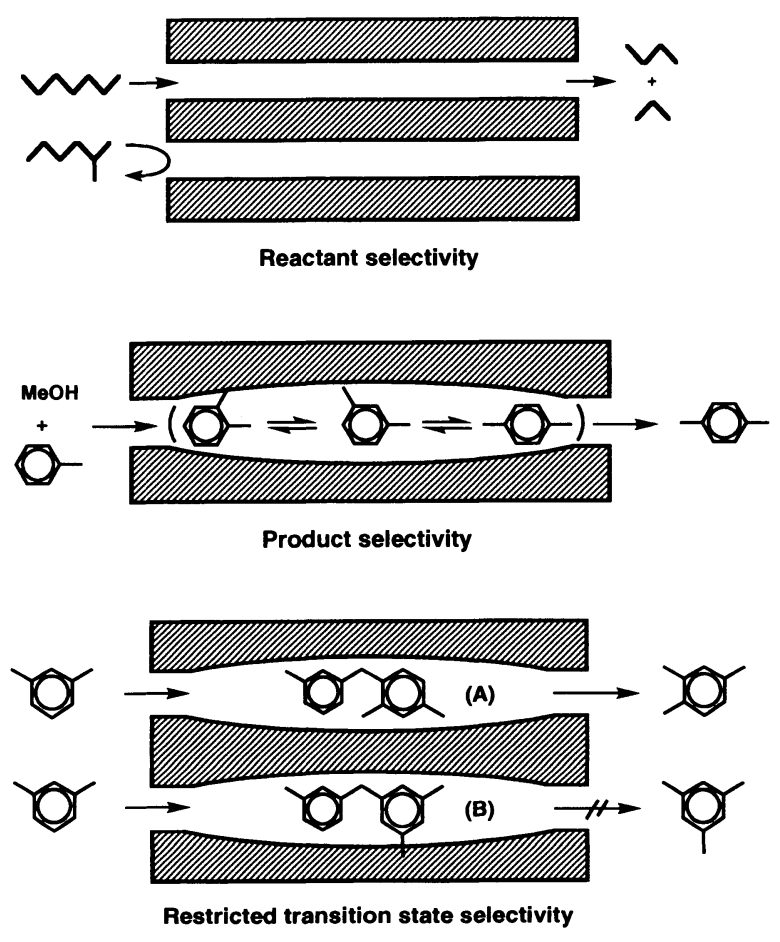

Fig. 1 Mechanism of Shape-selective Catalysis

孔している。ゼオライトの結晶外表面積は空孔内表面積に比べ 通常 $1 \%$ 以下であるため, 触媒活性点は主に空孔内に存在する。 反応に関与する分子 (基質, 遷移状態, 生成物等) と空孔の幾 何学的関係により反応が規制される。すなわち, 基質, 遷移状 態, 生成物等と空孔との相互作用に基づいて発現する選択性を 形状選択性と称する2)。これらの選択性は，Fig. 1 に示した反 応物規制（Reactant Selectivity），生成物規制（Product Selectivity）および遷移状態規制（Restricted Transition State Selectivity）のいずれかまたは複合して発現する2)。以下，本研 究の基礎となるこれらの選択性に関し, 簡単に述べる。

\section{1. 反応物規制}

反応物規制は空孔内に進入の可否による規制である。たとえ ば, H-ZSM-5 触媒によるへキサンおよびへプタン異性体のク ラッキング活性は各異性体の分子径により異なる。すなわち, ヘプタンと 3-メチルヘキサンの混合物を H-ZSM-5 を触媒とし て反応させると, 分子径の小さいヘプタンは空孔内に進入しク ラッキング反応を受けるが, 分子径の大きい3-メチルヘキサ ンは空孔内に進入できないので反応しない299。このように, 反 応基質に対する分子ふるい作用により発現する選択性を「反応 物規制による形状選択性」と称する2)。

\section{2. 生成物規制}

生成物規制は，生成する各異性体のうち最も小さい異性体が 優先的に生成する規制である。たとえば，H-ZSM-5 触媒によ る $m$-キシレンの異性化反応において, 空孔内では 3 種の異性 体間で異性化が起こるが, このうち最も拡散速度が大きい $p$ キシレンが空孔外に拡散し易いので, 液相生成物としては $p$ キシレンが優先的に生成される30),31)。このように，複数の生成 物が空孔内で生成する場合, 分子径の小さい化合物が優先的に
生成物として空孔外に拡散するが, 分子径の大きい化合物は空 孔外に拡散しにくいので, 異性化, 分解等の二次的反応により， より小さい分子に変換されてから空孔外に拡散し, 生成物とな る。このような生成物の分子径の差により発現する選択性を 「生成物規制による形状選択性」と称する2)。

\section{3. 僄移状態規制}

遷移状態规制は，ゼオライト空孔内で反応が進行する際，遷 移状態のかさ高さに差がある際に最も小さい生成物を優先的に 生成する規制である。たとえば，HM による $m$-キシレンの不 均化においては，1,2,4-トリメチルベンゼンの選択率が1,3,5-卜 リメチルベンゼンに比べて高い32)。この選択性は, ジフェニル アルカン中間体およびこれを生成する遷移状態のかさ高さの差 により決定される。すなわち, 遷移状態（B）に比べ遷移状態 (A) の方が空孔との立体的相互作用が小さいので，(A）を経 由する 1,2,4-トリメチルベンゼンの選択率が高くなると考えら れる。このように，遷移状態の幾何学的な差に基づく規制によ り発現する選択性を「遷移状態規制による形状選択性」と称す $ろ^{2)}$ 。

\section{3. 実験}

H-ゼオライト（HM，HY および HL）触媒は東ソー(株)から 提供されたものを用いた。HM のセリウム担持は硝酸セリウム のエタノール溶液から含浸法により行った。この際，セリウム 担持量は HM に対するセリウム重量で表す。ビフェニル，ナ フタレンおよび p-ターフェニルは特級試薬を, エチレン, プ ロピレンおよび 1-ブテンは試薬 1 級をそのまま用いた。アル キル化反応は一定圧のアルケンの存在下，無溶媒で，または trans-デカリンを溶媒とし一定量のプロピレンの存在下で行っ た。生成物の分析はガスクロマトグラフ (カラム: Ultra-1, 0.1 $\mathrm{mm} \times 25 \mathrm{~m}$ (ビフェニル); $\mathrm{TC}-17,0.1 \mathrm{~mm} \times 30 \mathrm{~m}$ (ナフタレン) $)$ を用いた。また，生成物の同定は同一カラムを用いる GC-MS により行った。反応後の触媒に包接されるビフェニルおよびナ フタレン誘導体は，フッ化水素酸で分解した懸濁液から有機物 をトルエンで抽出し，炭酸カリウムで中和後，反応生成物と同 様の条件で分析した。

1,3,5-トリイソプロピルベンゼン $(1,3,5-\mathrm{TIPB})$ のクラッキン グ速度は，気相流通反応装置を用い， $350^{\circ} \mathrm{C}$ で測定した ${ }^{33)}$ 。ナ フタレンおよび 2,6-イソプロピルナフタレン（2,6-DIPN）の吸 着は, $4 \%$ TIPB 溶液を室温で 24 時間吸着させた後, 残存量を 測定した。

熱重量分析はマックサイエンス TG-DTA2000 型熱分析計で 行った。測定条件は, 空気中, 試料 $10 \mathrm{mg}$, 昇温速度 $10^{\circ} \mathrm{C} / \mathrm{min}$ である。

アンモニア昇温脱離（ $\left.\mathrm{NH}_{3}-\mathrm{TPD}\right)$ スペクトルは八嶋らの方法 により測定した ${ }^{33)}$ 。触媒 $10 \mathrm{mg}$ を $500^{\circ} \mathrm{C}, 2$ 時間排気処理し, $150^{\circ} \mathrm{C}$ で 30 分間アンモニアを吸着させた後, $150^{\circ} \mathrm{C}$ で再度排気 した。室温に戻した後, $600^{\circ} \mathrm{C}$ まで $10^{\circ} \mathrm{C} / \mathrm{min}$ で昇温し, 触媒 から脱離するアンモニアを質量分析計で分析した。

アンモニア吸着熱は，(株) 東京理工 HAC-450G 型カロリー メーターにより $450^{\circ} \mathrm{C}$ で 5 時間排気処理した後, $200^{\circ} \mathrm{C}$ で測定 した。X 線回折（XRD）の測定は(株)マックサイエンス MXP19 型回折計により行った。走査型顕微鏡（SEM）観察および 


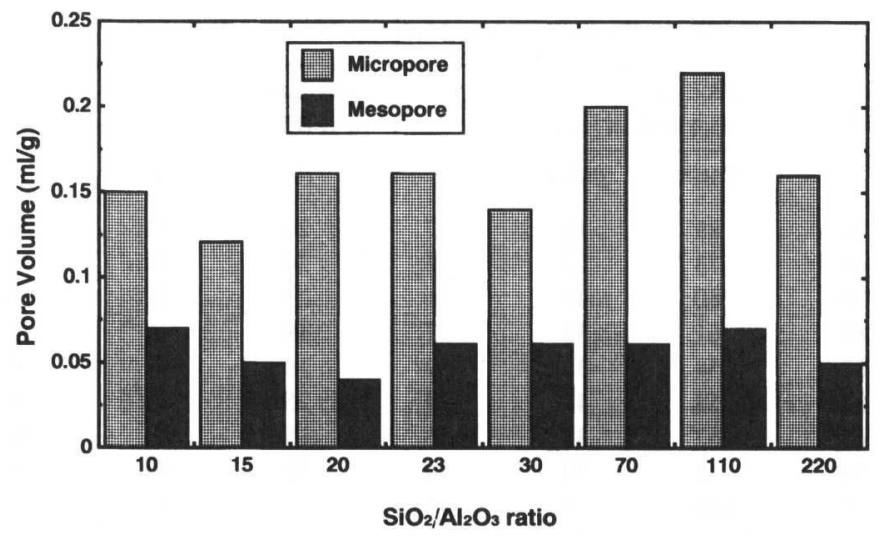

Fig. 2 Effect of Dealumination of HM on Pore Volumes

エネルギー分散 X 線 (EDX) スペクトルの測定は(株) 日立製 作所 S-800 型顕微鏡により行った。 ${ }^{129} \mathrm{XeNMR}$ スペクトルは Bruker 社 AM300 型スペクトロメーターにより $83.0 \mathrm{MHz}$ で測 定した。

\section{H-モルデナイトのキャラクタリゼーション}

本研究で用いた HM は東ソー(株) から提供されたものであ り, $\mathrm{SiO}_{2} / \mathrm{Al}_{2} \mathrm{O}_{3}$ 比が 23 以上のものは, 酸による脱アルミニウ ム処理により調製したものである。触媒物性と反応挙動を明ら かにするために各種物性を検討した。

脱アルミニウムによる空孔容積の変化を Fig. 2 に示した。 脱アルミニウムによる表面積およびメソポアの増加は見られ ず，またミクロポアの変化にも規則性が認められなかった28)。 $\mathrm{X}$ 線回折は脱アルミニウム後も結晶構造が保持されることを示 している7。

$\mathrm{X}$ 線光電子スペクトルから推定した外表面のアルミニウム濃 度と蛍光 X 線スペクトルから推定したバルクのアルミニウム 濃度を Fig. 3 に示した。両者にほとんど差が認められないこ とから, 脱アルミニウムはほほ均一に起こると考えられる9”。 なお, 図中の点線は, 結晶内外表面からの均一な脱アルミニウ ムを仮定した際の関係である。

吸着アンモニアの昇温脱離ピーク温度は酸強度の指標として 知られている。Fig. 3 に示したように, 本研究で用いた触媒の 酸強度は脱アルミニウムにより低下するが, $\mathrm{SiO}_{2} / \mathrm{Al}_{2} \mathrm{O}_{3}$ 比が 50 以上ではほほ一定となることがわかった9)。

\section{5. ビフェニルのアルキル化反応}

\section{1. 各種ゼオライト触媒の選択性}

各種ゼオライトを触媒とするビフェニルのイソプロピル化反 応の結果を Table 1 に示した7),91,10)。12 員環空孔を有する HM, HY および HL は, それぞれ全く異なる触媒活性および選択性 を示した。HM は, 立体的に最も小さい4-イソプロピルビフェ ニル（4-IPBP） および 4,4'-ジイソプロピルビフェニル（4,4'DIPB）を選択的に与えたが, HY および HL では, これらの異 性体の選択性が低く, 無定形シリカ・アルミナ（SA）とほほ 同等であった。また，10 員環を有する H-ZSM-5 は触媒活性 が低かった。このようにゼオライトにより選択性に差が現れる

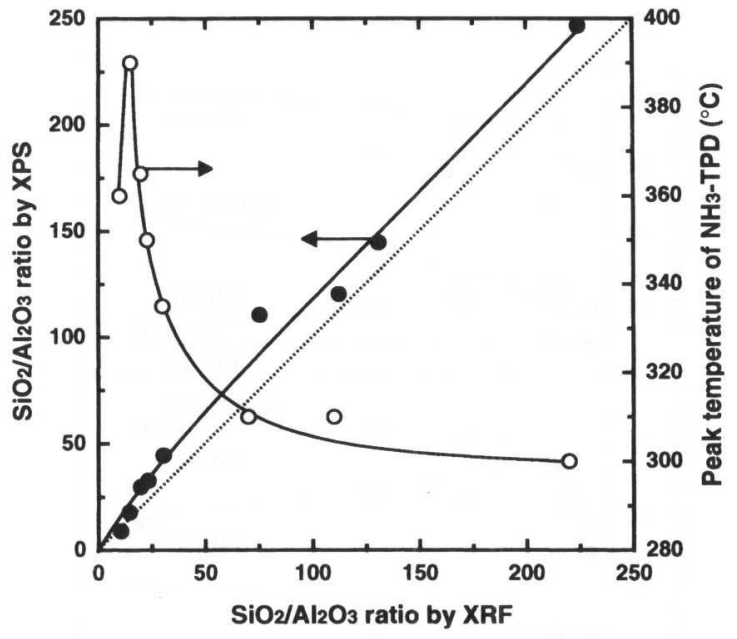

Fig. 3 Effects of $\mathrm{SiO}_{2} / \mathrm{Al}_{2} \mathrm{O}_{3}$ Ratio on Bulk and External Surfaces and on Peak-top Temperature of $\mathrm{NH}_{3}$-TPD

ことは, 構造および空孔径が異なるため活性点の位置および遷 移状態の立体規制に差が生じることに基づくものである。

12 員環ゼオライトでは, 空孔内で反応が主として進行する と考えられる。この際, 最も空孔径が小さい HM では, IPBP および DIPB 各異性体を生成する遷移状態に差があり，立体的 に最も小さい 4-IPBP および 4,4'-DIPB の生成に有利であるが, 一方で HY および HL では, 空孔径がより大きいために反応場 における立体規制が小さいので形状選択性は発現しないと考え られる。さらに, H-ZSM-5 はビフェニルのアルキル化の反応 場として必要な大きさがないことを示している。

\section{2. H-モルデナイトの脱アルミニウムの効果}

HM には 12 員環空孔と 8 員環空孔が存在する。このうち, 8 貝環空孔はかさ高い有機分子が進入するには狭すぎるので, 多 環芳香族炭化水素が関与する反応は, 事実上一次元空孔である 12 員環空孔内で起こると考えられる。このために, 炭素質生 成による空孔閉そくを起こし易く，短時間で失活することが多 (35) -37)。しかし，これらの失活は脱アルミニウムを行うこと

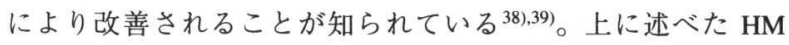


Table 1 Zeolite Catalyzed Isopropylation of Biphenyl

\begin{tabular}{|c|c|c|c|c|c|c|c|c|c|c|}
\hline \multirow{2}{*}{$\begin{array}{l}\text { Catalyst } \\
\left(\mathrm{SiO}_{2} / \mathrm{Al}_{2} \mathrm{O}_{3}\right)\end{array}$} & \multirow{2}{*}{$\begin{array}{l}\text { Temp. } \\
{\left[{ }^{\circ} \mathrm{C}\right]}\end{array}$} & \multirow{2}{*}{$\begin{array}{c}\text { Conv. } \\
{[\%]}\end{array}$} & \multicolumn{2}{|c|}{$\begin{array}{l}\text { Product } \\
\text { distribution [\%] }\end{array}$} & \multicolumn{3}{|c|}{$\begin{array}{l}\text { Distribution } \\
\text { of IPBP [\%] }\end{array}$} & \multicolumn{3}{|c|}{$\begin{array}{l}\text { Distribution } \\
\text { of DIBP [\%] }\end{array}$} \\
\hline & & & IPBP & DIBP & $2-$ & $3-$ & 4- & $4,4^{\prime}-$ & $3,4^{\prime}-$ & $3,3^{\prime}-$ \\
\hline \multirow[t]{2}{*}{$\mathrm{HM}(23)$} & 180 & 16 & 89 & 11 & 7 & 20 & 74 & 75 & 16 & 2 \\
\hline & 250 & 48 & 73 & 27 & 5 & 24 & 71 & 78 & 14 & 2 \\
\hline \multirow[t]{2}{*}{ HY(6) } & 200 & 76 & 60 & 40 & 36 & 23 & 41 & 5 & 8 & 7 \\
\hline & 250 & 83 & 61 & 33 & 7 & 48 & 45 & 11 & 22 & 13 \\
\hline \multirow[t]{2}{*}{ HL(6) } & 200 & 82 & 54 & 36 & 39 & 18 & 43 & 10 & 8 & 6 \\
\hline & 250 & 84 & 53 & 47 & 29 & 25 & 46 & 10 & 13 & 6 \\
\hline \multirow[t]{2}{*}{$\mathrm{SA}(4)$} & 180 & 67 & 62 & 38 & 36 & 15 & 49 & 16 & 9 & 5 \\
\hline & 250 & 84 & 48 & 39 & 18 & 32 & 50 & 25 & 26 & 8 \\
\hline H-ZSM-5(50) & 300 & 6 & 100 & 0 & 16 & 30 & 54 & - & - & - \\
\hline
\end{tabular}

Reaction conditions: biphenyl, $50 \mathrm{mmol}$; propylene, $100 \mathrm{mmol}$; solvent, trans-decalin, $20 \mathrm{ml}$; catalyst, $1 \mathrm{~g}$; period, $4 \mathrm{~h}$.

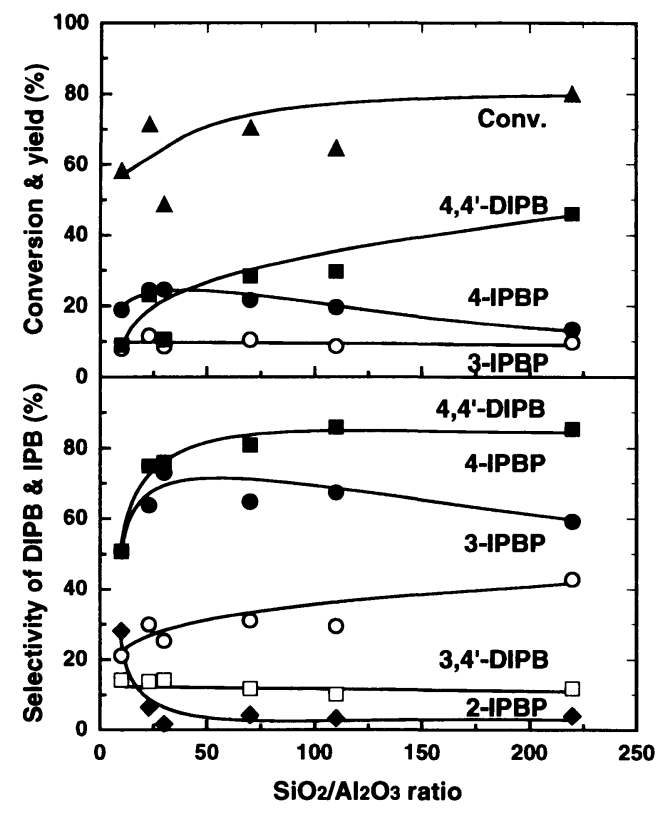

Reaction conditions: biphenyl, $200 \mathrm{mmol}$; HM, $2 \mathrm{~g}$; propylene pressure, $0.8 \mathrm{MPa}$; temperature, $250^{\circ} \mathrm{C}$; period, $4 \mathrm{~h}$.

Fig. 4 Effect of Dealumination of HM on Isopropylation of Biphenyl

(23)*1) によるビフェニルのイソプロピル化反応においても多 量の炭素質生成が認められたので，脱アルミニウムしたHMを 用いて $\mathrm{SiO}_{2} / \mathrm{Al}_{2} \mathrm{O}_{3}$ 比の効果を検討した ${ }^{8), 10), 12) ~ 17) 。 F i g . ~} 4$ に示 したように，比を高くすると，触媒活性の向上とともに4IPBP および 4,4'-DIPB の選択性が向上した。特に, HM(220) では 4,4'-DIPB 選択率が $90 \%$ 近くに，また収率も50\%に達し た。すなわち, 脱アルミニウムにより酸濃度が滅少するにもか かわらず HM の触媒機能が著しく改善された。この際, 反応 に用いた触媒の $\mathrm{TG}$ 分析によると, $\mathrm{SiO}_{2} / \mathrm{Al}_{2} \mathrm{O}_{3}$ 比とともに炭素 質生成が隇少し，触媒活性と炭素質生成に相関関係が存在した (Fig. 5)。これらの事実は, 脱アルミニウムによる HM の活性

*1) カッコ内の数字は $\mathrm{SiO}_{2} / \mathrm{Al}_{2} \mathrm{O}_{3}$ 比を示す。

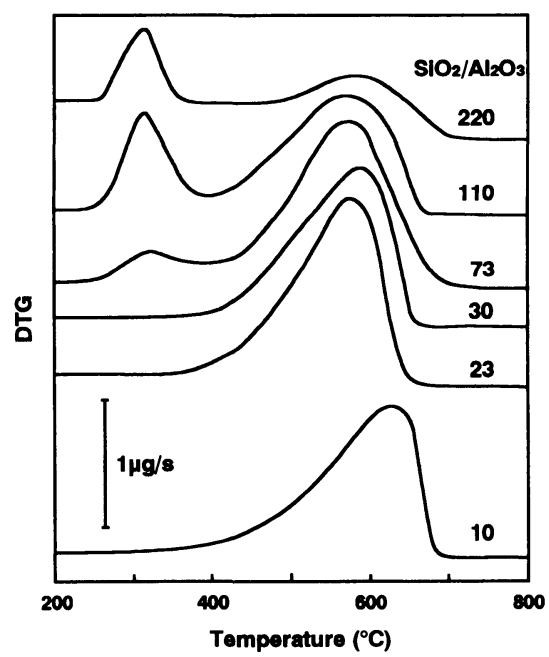

Reaction conditions: see Fig. 4.

Fig. 5 Effect of Dealumination of HM on Coke Deposition in Isopropylation of Biphenyl

および形状選択性の向上は, 酸点の隇少および酸強度の低下に 基づく炭素質の生成量の減少によるものであり，アルキル化に 関与する $\mathrm{HM}$ の酸点は $\mathrm{SiO}_{2} / \mathrm{Al}_{2} \mathrm{O}_{3}$ 比にかかわらず少量である ことを示している。

触媒に包接された生成物は空孔内で起こる反応を明らかにす る上で重要な情報となる。 $\mathrm{SiO}_{2} / \mathrm{Al}_{2} \mathrm{O}_{3}$ 比が 73 以上の $\mathrm{HM}$ の $\mathrm{TG}$ 分析では，炭素質に起因するピーク以外に有機物と考えられる ピークが観測された。これらのピークは触媒中に包接された生 成物に基づくと考えられるので, 触媒を分解し, 包接されたビ フェニル誘導体の分布を検討した ${ }^{(5) ~ 17) 。 F i g . ~} 6$ に，液相中お よび触媒中に包接された DIPB 誘導体中の 4,4'- および 3,4'DIPB の選択率を示した。触媒中の 4,4'-DIPB の選択率は, $\mathrm{SiO}_{2} / \mathrm{Al}_{2} \mathrm{O}_{3}$ 比にかかわらず, ほほ一定であり, 先に述べた液相 中の生成物分布とは全く異なることがわかる。これらの事実は, $\mathrm{SiO}_{2} / \mathrm{Al}_{2} \mathrm{O}_{3}$ 比の变化に伴う 4,4'-DIPB 選択率の変化は, $\mathrm{HM}$ 空 孔の形状選択性の変化に伴うものではなく, 炭素質による空孔 閉そくに基づくことを示している。すなわち, $\mathrm{SiO}_{2} / \mathrm{Al}_{2} \mathrm{O}_{3}$ 比が 


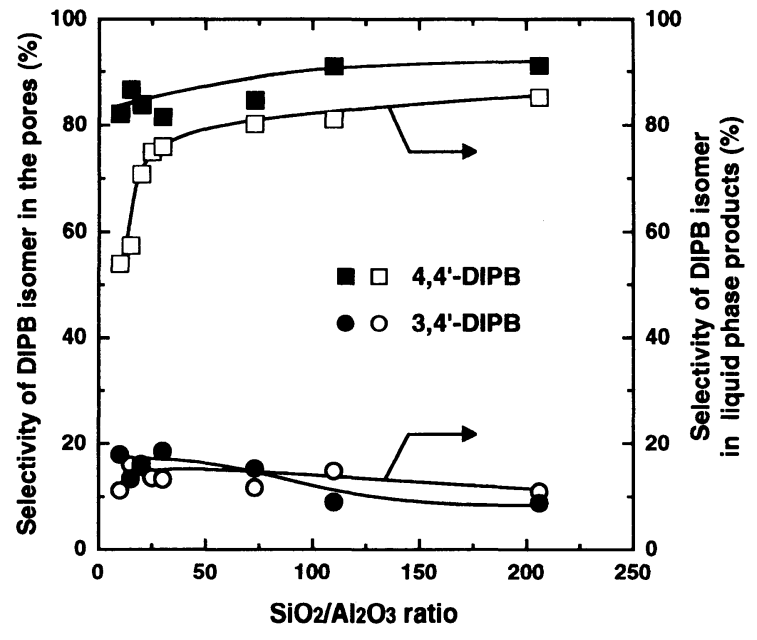

Reaction conditions: see Fig. 4.

Fig. 6 Effect of Dealumination on Product Distribution of Encapsulated DIPB Isomers inside the Pores and of Bulk Products in Isopropylation of Biphenyl

低い HM(10) のような触媒では, 空孔内では形状選択的イソ プロピル化反応が起こるが，炭素質生成による空孔閉そくが起 こるために，生き残った外表面酸点における非選択的反応が関 与し，4,4'-DIPB の選択性が低下すると考えられる。

以上述べたように，脱アルミニウムを行った HM を触媒と するビフェニルのイソプロピル化では, 空孔内において形状選 択的反応が円滑に進行する。著者らは，この選択性が，空孔と の立体的相互作用の少ない最もコンパクトな遷移状態を経由す る 4,4'-DIPB の生成が有利となることにより発現すると考えて いる。しかし, この選択性が, 空孔内で非選択的反応で生成し たDIPB 異性体のうち最もスリムで拡散速度の大きい 4,4' DIPB が優先的に空孔外から拡散される機構, すなわち生成物 規制に基づき発現する可能性がある。しかし，Fig. 6 に示した ように $\mathrm{SiO}_{2} / \mathrm{Al}_{2} \mathrm{O}_{3}$ 比にかかわらず触媒に包接された $4,4^{\prime}-\mathrm{DIPB}$ の選択率が高いことから，生成物規制がビフェニルのイソプロ ピル化反応において作用する可能性は低いと考えている ${ }^{15) ~ 17) 。 ~}$

Garces らは, Zeolon 100 を原料として高度な脱アルミニウム $\left(\mathrm{SiO}_{2} / \mathrm{Al}_{2} \mathrm{O}_{3}=2600\right)$ を行った $\mathrm{HM}$ は非常に高活性および高寿 命を有することを見い出した40)。本触媒は, 酸点が非常に少量 であるにもかかわらず，触媒活性が非常に高く，70\%以上の 収率で 4,4'-DIPB を生成した。高度の脱アルミニウムによるメ ソポアの増加により HM 空孔への基質の接近および空孔から の生成物の排出が容易になり，4,4'-DIPB の生成には Derouane ら ${ }^{41)}$ の提唱した Molecular Traffic Control が作用するとしてい る。すなわち, 反応はメソポアに開孔する12 貝環空孔内で起 こるが, プロピレンは（少なくとも一部は） 12 員環空孔に直 交する 8 員環空孔から進入する。この際, 空孔内ではビフェニ ルの両端に対するイソプロピル化が起こり 4,4'-DIPB を生成す るとした。しかし, 著者らの用いたHMは脱アルミニウム度が 低いので，これらの触媒と直接比較することは困難である。特 に，著者らの範囲内ではメソポアの増加は認められなかった。

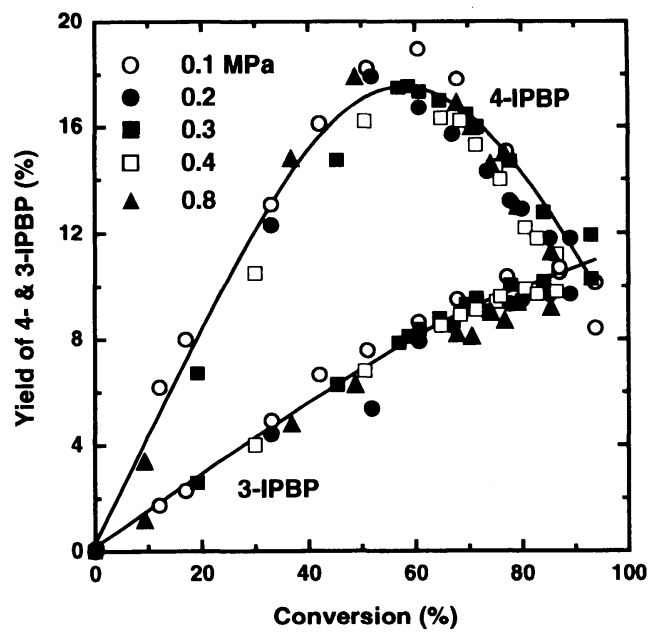

Reaction conditions: biphenyl, $400 \mathrm{mmol} ; \mathrm{HM}(220), 2 \mathrm{~g}$; propylene pressure, $0.1-0.8 \mathrm{MPa}$; temperature, $250^{\circ} \mathrm{C}$.

Fig. 7 Effect of Propylene Pressure on Yields of 4- and 3IPBP in Isopropylation of Biphenyl

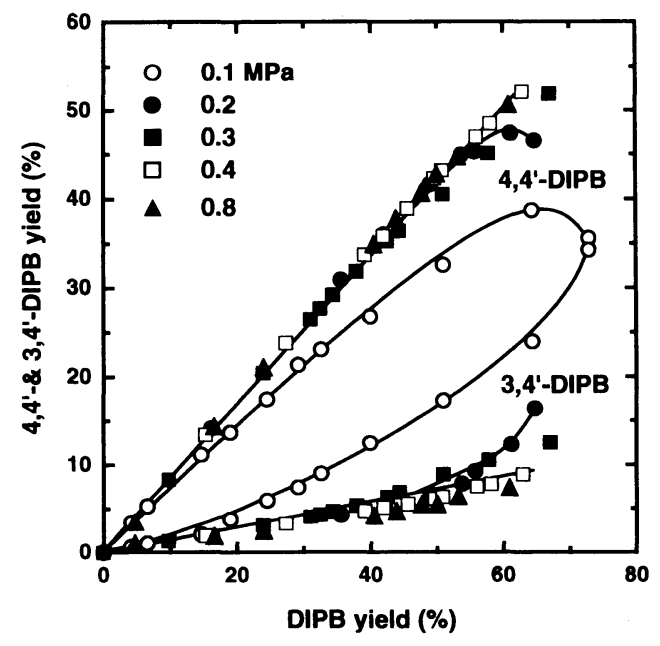

Reaction conditions: see Fig. 7.

Fig. 8 Effect of Propylene Pressure on Yields of 4,4'- and 3,4'-DIPB in Isopropylation of Biphenyl

いずれにしろ高度の脱アルミニウムのために, 酸点濃度が非常 に低く,メソポアにより寸断された HM 空孔において立体規 制が作用し, 形状選択性が発現することは興味ある事実であ る。

\section{3. プロピレン圧カの影隌}

HM(220) によるビフェニルのイソプロピル化におけるプロ ピレン圧力が生成物分布に与える影響を Figs. 7 および 8 に示 した 14),177,20),21)。IPBP 異性体の収率には圧力の影響は認められ ず,ほほ同一の曲線上にプロットされた（Fig. 7)。この際，4IPBP の生成には極大が認められ, 反応率が約 50〜60\% で最大 になったが,ささらに反応率が高くなると収率が減少した。一方, 


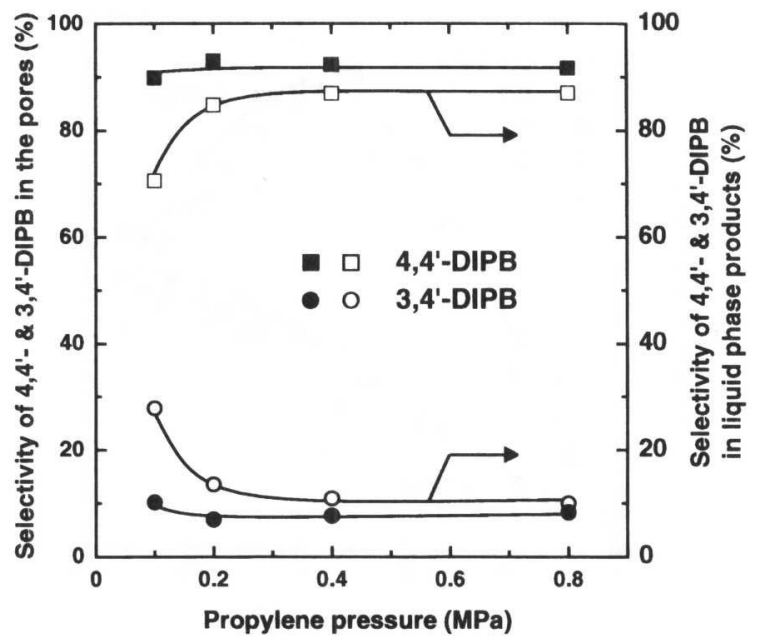

Reaction conditions: biphenyl, $200 \mathrm{mmol}$; HM(206), $1 \mathrm{~g}$; propylene pressure, $0.1-0.8 \mathrm{MPa}$; temperature, $250^{\circ} \mathrm{C}$; period, 4 h.

Fig. 9 Effect of Propylene Pressure on Product Distribution of Encapsulated 4,4'- and 3,4'-DIPB inside the Pores and of Bulk Products in Isopropylation of Biphenyl

3-IPBP は反応率とともに単調に増加した。両異性体の挙動の 差はかさ高さの差によるものであり, DIPB 異性体の生成には 反応物規制が作用し 4-IPBP から 4,4’-DIPB を生成するが，よ りかさ高い 3-IPBP は DIPB の生成に関与しにくいことを示し ている。Fig. 8 に 4,4'- および 3,4'-DIPB の生成に対する圧力効 果を示した。プロピレン圧 $0.3 \mathrm{MPa}$ 以上では, 全 DIPB 異性体 収率に対し 4,4'-DIPB 収率はほぼ同一直線上にプロットされ， 反応中選択率が一定である。しかし, 圧力が $0.2 \mathrm{MPa}$ 以下では, 4,4'-DIPB 収率が直線関係から下方にずれる傾向がみられた。 特に $0.1 \mathrm{MPa}$ では,このずれが反応の進行とともに大きくなり， 4,4’-DIPB 収率は極大に達した後, 減少した。これに伴い, 3,4'-DIPB 収率が低圧では上方にずれ, 特に反応終期では急速 に増加した。これらの事実は，3,4'-DIPB はいったん生成した 4,4'-DIPB が異性化することにより生成することを示している。 この際, 触媒中に包接された DIPB 異性体中の 4,4'-DIPB 選択 率は, 圧力にかかわらずほぼ一定であり, 液相中の 4,4'-DIPB 選択率の変化と異なることがわかった（Fig. 9）。これらの事 実は, 4,4'-DIPB の異性化反応は空孔内では起こらないことを 示している。

この異性化の機構を明らかにするために，プロピレンの存在 下で 4,4'-DIPB と HM(220) を処理した (Fig. 10 14).17).20).21)。 プロピレンの存在しない条件, または $0.2 \mathrm{MPa}$ 以下の低い圧力 では，異性化生成物である 3,4’-DIPB が生成した。しかし，0.3 $\mathrm{MPa}$ 以上では，異性化生成物およびトリイソプロピルビフェ ニル（TrIPB）の生成は少量であり，4,4'-DIPB の異性化および アルキル化が高圧下では起こり難いことがわかる。一方, 触媒 中に包接された DIPB 異性体は圧力にかかわらずほほ 4,4 ' DIPBのみであった。以上の結果は, 4,4'-DIPB の異性化は空孔 内ではなく, 外表面で起こることを示している。これらの反応 の圧力効果はプロピレンの酸点への吸着と関係するものと考え

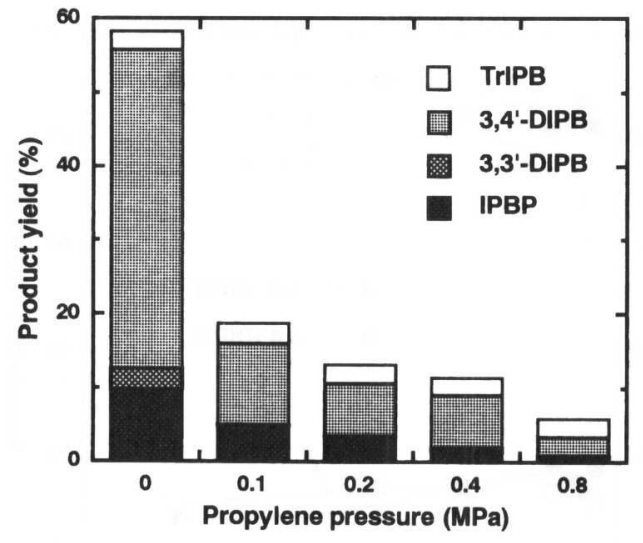

Reaction conditions: 4,4'-DIPB, $100 \mathrm{mmol}$; $\mathrm{HM}(220), 1 \mathrm{~g}$; temperature, $250^{\circ} \mathrm{C}$; period, $4 \mathrm{~h}$.

Fig. 10 Effect of Propylene Pressure on Isomerization of $4,4^{\prime}$ DIPB

られる。すなわち, 高圧下では外表面での異性化がプロピレン の優先的吸着により抑制されるが，低圧下では 4,4'-DIPB の吸 着がプロピレンに優先し，酸点に吸着した 4,4'-DIPB が異性化 すると説明できる。ビフェニルのイソプロピル化において も,プロピレン圧が低いときは 4,4'-DIPB の優先吸着による 4,4'-DIPB の異性化が起こると考えられる。

Fig. 10 に示したように, 高圧プロピレンの存在下でも 4,4'DIPB のイソプロピル化がほとんど起こらなかった 14),17),20),21)。 これは空孔内では反応に十分な空間がないこと，また4,4DIPBの 2- および 3-位が立体的に込み合っているために, 攻撃 を受けにくいことに起因すると思われる。低プロピレン圧下で 少量のTrIPBが認められるが, 4,4'-DIPB の異性化により生成し た立体的込み合いの小さい 3,4'-DIPB がイソプロピル化を受け たものと考えられる。

炭素質がどのようにして生成するかを明らかにするために, $\mathrm{HM}(220)$ によるビフェニルのイソプロピル化および 4,4'DIPB の異性化における炭素質生成とプロピレン圧の関係を調 ベた20)。プロピレンの存在下では, いずれの場合も $300^{\circ} \mathrm{C}$ 付近 に触媒に包接された有機化合物, および $600^{\circ} \mathrm{C}$ 付近に炭素質に 基づく重量減少が認められた。また，ビフェニルと HM(220) をプロピレンの存在しない条件で接触させても炭素質の生成は 認められないが, 4,4'-DIPB の場合はプロピレンの存在の有無 にかかわらず炭素質生成が認められた。以上の事実は，イソプ ロピル基を持つ化合物が炭素質生成の前駆物質として重要な役 割を担っていることを示している。しかし, 高度に脱アルミニ ウムされた HM 上における炭素質生成は少ないので, 触媒活 性は長期に持続されると考えられる。

坂本らは, HM によるビフェニルのイソプロピル化において 高プロピレン圧下で 4,4'-DIPB の選択率が改善されることを見 い出した42)。Fellmann は, 空孔内においてプロピレンが込み合 うために, 高プロピレン圧で形状選択性が改善されると推論し た43)。しかし，上に述べたようにこのプロピレン圧の効果は 4,4'-DIPB の異性化反応によるものであると考えられる。 


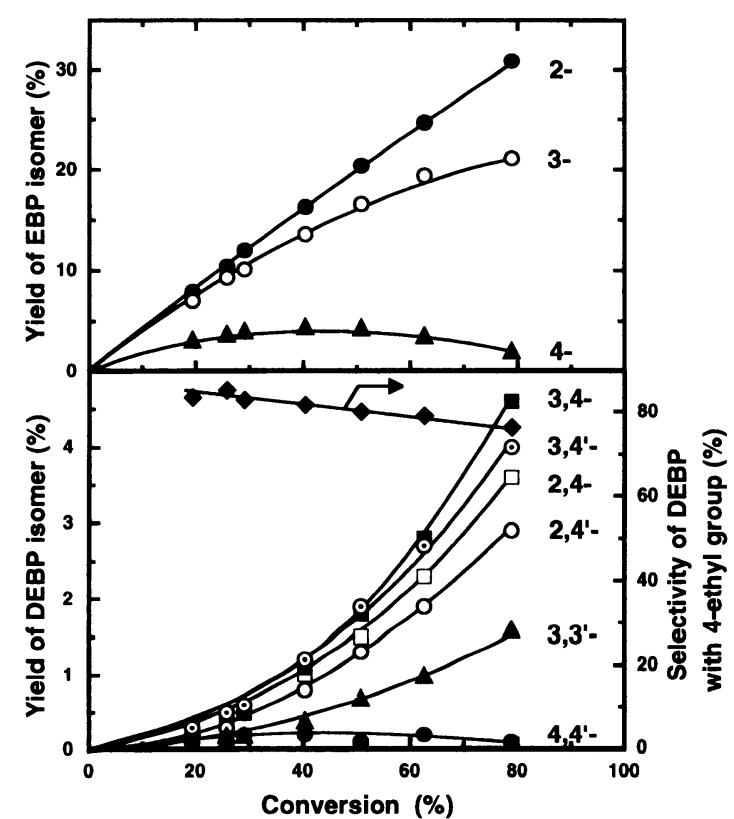

Reaction conditions: biphenyl $200 \mathrm{mmol}$, $\mathrm{HM}(206) 1 \mathrm{~g}$, ethylene, $0.8 \mathrm{MPa}$; temperature $220^{\circ} \mathrm{C}$.

Fig. 11 Profile of Ethylation of Biphenyl

\section{4. アルキル化剤およびアルキル置換基の影響}

前節までに述べたように, HM 空孔はビフェニルのイソプロ ピル化の反応場として有効であり，遷移状態規制に基づく高い 選択性が発現する。そこで, 触媒活性点における立体的要因を 検討するために, アルキル化剤およびアルキル基が反応に与え る影響を検討した22) 24)。

HM(206) によるビフェニルのエチル化の反応経過を Fig. 11 に示した ${ }^{23), 24)}$ 。イソプロピル化と異なり，立体的に最も小さい 4-エチルビフェニル (4-EBP) および 4,4'-ジエチルビフェニル (4,4’-DEBP) の収率が低かった。反応初期における EBP 異性 体の割合が 4-EBP : 3-EBP : 2-EBP=1:2:3に近いので, EBP 各異性体の生成は基質の各位置における反応性に支配されると 考えられる。しかし，反応が進むにつれ，EBP 異性体の挙動 に差が現れた。最も反応性に富む 4-EBP は，反応率 30～50\% で収率が最大となり, 以後減少した。また，3-EBP の収率は, 反応の進行とともに増大するが, 後期では増加率が低下するの で，3-EBP の一部は DEBP 生成反応に関与すると考えられる。 しかし，2-EBP は反応が進んでも直線的に収率が増加するの で, DEBP 異性体の生成に関与しない。この際, DEBP 異性体 に関しては特定異性体の優先的生成は認められなかったが, 4位にエチル基を持つ 2,4-，2,4'-，3,4-，3,4'- および 4,4'-DEBP の収率を併せると約 $80 \%$ に達することより, DEBP 異性体の 大部分は立体的に最も小さい 4-EBP 経由することがわかる。 これらの事実は, EBP 異性体の生成に関し各異性体のかさ高 さに基づく反応物規制が働くことを示している。一方，DEBP 各異性体のうち 4,4'-DEBP の収率は主要異性体中最も低く, 4EBP の場合と同様に生成量は反応率 30〜50\%において極大に 達し，反応の進行とともに滅少した。これは，立体的に最も小

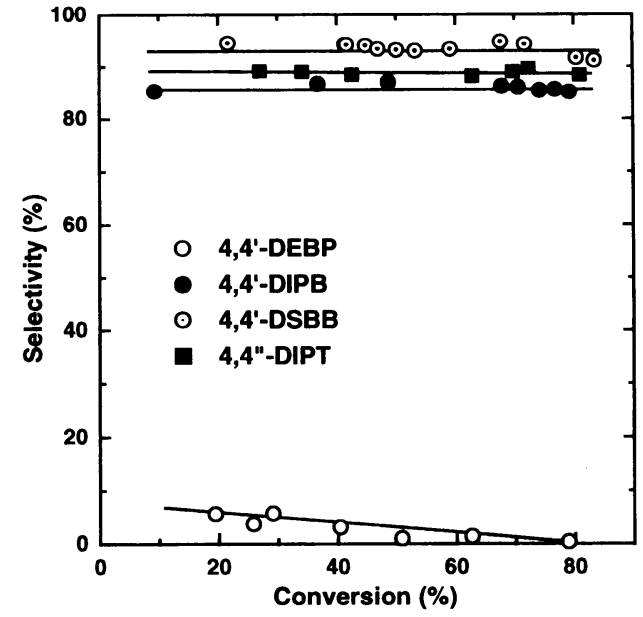

Reaction conditions

isopropylation of biphenyl and p-terphenyl: substrate, 400 mmol; HM(206), $2 \mathrm{~g}$; temperature, $250^{\circ} \mathrm{C}$; propylene, $0.8 \mathrm{MPa}$; $s$-butylation: biphenyl, $400 \mathrm{mmol} ; \mathrm{HM}(206), 2 \mathrm{~g}$; temperature, $250^{\circ} \mathrm{C}$; 1-butene, $0.5 \mathrm{MPa}$.

Conditions for ethylation of biphenyl: see Fig. 11.

Fig. 12 Selectivity of 4,4'-DABP and 4,4"-DIPT in Alkylation of Biphenyl and $p$-Terphenyl

さい 4,4'-DEBP が優先的にエチル化され, ポリエチルビフェニ ル（PEBP）を生成することを示している。なお, DEBP 異性 体中には 3,3'-DEBP が存在することから, 3-EBP も一部 DEBP 異性体の生成に関与すると考えられる。

ビフェニルのアルキル化におけるアルキル化剂の影響を Fig. 12 に示した23),24)。エチレンとプロピレンおよび 1-ブテンの間 には選択率に大きな差が認められた。すなわち, エチレンでは 4,4'-DEBP の選択率は極端に低く，また反応中に低下する傾向 が認められた。一方, プロピレンおよびブテンでは 4,4'-DIPB および 4,4'-ジ-s-ブチルビフェニル (4,4'-SBBP) が選択的に生 成し, 反応中一定であった。Fig. 12 に併せ示したように,pターフェニルのイソプロピル化もビフェニルと同様に 4,4”-ジ イソプロピル-p-ターフェニル (4,4”-DIPT) を高い選択率で与 えた。以上の差は, アルキル化剂のかさ高さによる遷移状態の 立体的規制の差によると考えられる。すなわち, エチレンでは 遷移状態規制が作用しないために 4,4'-DEBP の選択率が低い が, プロピレン以上のアルキル化剤では遷移状態規制が有効に 作用するために立体的に最も小さい 4,4 '-ジアルキルビフェニ ル（4,4'-DABP） および 4,4”-DIPTを高い選択率で生成すると 考えられる。

ビフェニルのアルキル化に与える 4-アルキル基の影響を Fig. 13 に示した 23),24)。4,4'-DABP の選択率は置換基のかさ高さを反 映し, 4-メチルビフェニル (4-MBP) < 4-EBP<4-IPBP の順に 向上した。なお, ビフェニルのイソプロピル化において，4IPBP は 4,4'-DIPB の生成中間体であるために, 選択率は反応 の進行とともに変化した。このために反応初期における 4IPBP の選択率から推定されるビフェニルの 4-水素の立体的影 響は他の 4'-アルキルビフェニルに比べて低いと判断される。 さらに, $p$-ターフェニルのモノイソプロピル化により生成した 


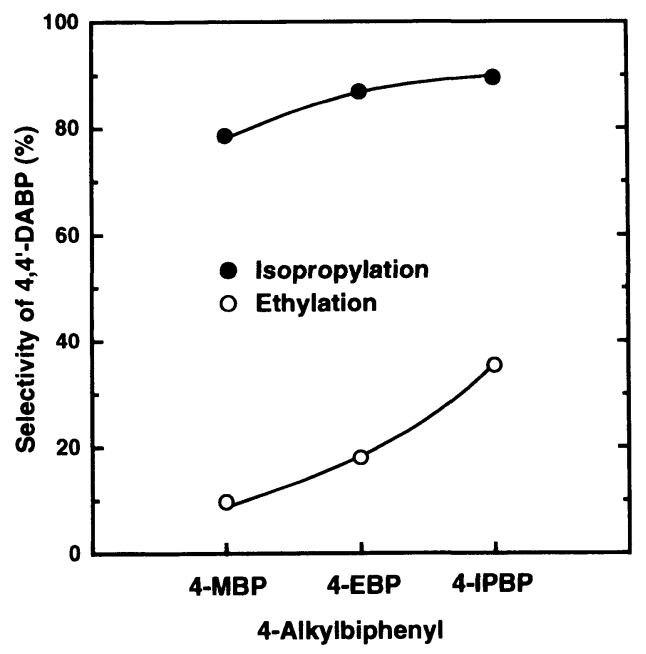

Reaction conditions: biphenyls, $100 \mathrm{mmol}$; $\mathrm{HM}(206) 2 \mathrm{~g}$; temperature, $250^{\circ} \mathrm{C}$ (ethylation of $4-\mathrm{EBP}, 220^{\circ} \mathrm{C}$ ); propylene or ethylene, $0.8 \mathrm{MPa}$; period, $4 \mathrm{~h}$ (ethylation of 4-EBP $0.5 \mathrm{~h}$ ).

Fig. 13 Isopropylation and Ethylation of 4-ABP

4-イソプロピル-p-ターフェニル（4-IPTP）の選択率は，この異 性体が優先的に 4,4”-DITPに変換されるために, 反応の進行と ともに減少する傾向が認められた。しかし，反応初期において は高い選択率を示し, 空孔内における 4-フェニル基の立体規 制が 4-イソプロピル基に比べ大きいと推定される。一方，4MBP, 4-EBP および 4-IPBP のエチル化では上記のイソプロピ ル化で見られた高選択率は観測されず，それぞれ 14，25およ び $36 \%$ であった。これらのエチル化では, イソプロピル化と 異なり，遷移状態における立体規制が大きくないと考えられる。 以上の結果は, これらの反応の形状選択性が主としてアルキル 化剤のかさ高さにより支配され，4-位の置換基の効果は副次的 であることを示している。

\section{6. ナフタレンのイソプロピル化}

\section{1. ゼオライト触媒の選択性}

各種ゼオライト触媒によるナフタレンのイソプロピル化の代 表的な生成物分布を Table 2 に示した ${ }^{34), 44)}$ 。HM(25) は, 活性 は低いが, 高い $\beta, \beta$-選択性を示し, 2,6-および 2,7-DIPNを主と して含む生成物を与えた。この際, 2,6-DIPN 選択率が 2,7DIPN に比べて高い選択率で生成することから，HM がナフタ レンのイソプロピル化において形状選択性を発現することがわ かる。一方, HY および HLでは, 反応条件により異なる生成 物分布を与えた。すなわち, 低温では 1-および4-位にアルキ ル化された 1,4- および 1,6-DIPN が高い選択率で生成した。一 方, 反応温度を高くすると，1,3-，2,6- および 2,7-DIPN が主と して生成した。これらのゼオライトの空孔は HM に比べて大 きいので, 遷移状態における立体規制が働かないことを示して いる。反応温度が低い時または反応初期において速度論的規制 を受け, 電子密度の最も高い $\alpha$-位がアルキル化された $\alpha, \alpha$-異 性体, 特に 1,4-/1,5-DIPN が主生成物となる。しかし, 高温ま たは反応が進むにつれ，熱力学的規制を受けるようになり，よ り安定な異性体である $\alpha, \beta-/ \beta, \beta$-異性体, 特に 1,3-, 2,6- および 2,7-DIPN を優先的に生成すると考えられる。なお，H-ZSM-5 は $240^{\circ} \mathrm{C}$ において触媒活性がほとんど認められなかった。

\section{2. H-モルデナイトの脱アルミニウム効果}

上記のように, HM によるナフタレンのイソプロピル化はビ フェニルの場合と同様に形状選択性が発現したので, 脱アルミ ニウムによる活性および選択性の影響を調べた ${ }^{8), 25)}$ 。反応率 $80 \%$ におけるイソプロピルナフタレン（IPN）および DIPN 異 性体の収率および選択率は Fig. 14 に示したように HMの $\mathrm{SiO}_{2} / \mathrm{Al}_{2} \mathrm{O}_{3}$ 比に依存した。特に, $\mathrm{SiO}_{2} / \mathrm{Al}_{2} \mathrm{O}_{3}$ 比 30 以下では, DIPN 収率が低く, IPN およびポリイソプロピルナフタレン (PIPN) の生成が著しかった。この際，2-IPN，2,6- および 2,7DIPN 等の $\beta$-または $\beta, \beta$-異性体の選択率が低く, $\alpha$-イソプロピ ル基を有する DIPN 異性体, 特に 1,6-DIPN の選択率が高かっ た。しかし, 脱アルミニウムした $\mathrm{SiO}_{2} / \mathrm{Al}_{2} \mathrm{O}_{3}$ 比の高い $\mathrm{HM}$ で は, DIPN 異性体の収率が増加し, IPN および PIPN の収率は 隇少した。この際, $\beta$-および $\beta, \beta$-異性体, 特に 2-IPN および 2,6-DIPN の選択率が向上した。 $\mathrm{SiO}_{2} / \mathrm{Al}_{2} \mathrm{O}_{3}$ 比 70 以上でこれら

Table 2 Zeolite Catalyzed Isopropylation of Naphthalene

\begin{tabular}{|c|c|c|c|c|c|c|c|c|c|c|c|}
\hline \multirow{2}{*}{$\begin{array}{l}\text { Catalyst } \\
\left(\mathrm{SiO}_{2} / \mathrm{Al}_{2} \mathrm{O}_{3}\right)\end{array}$} & \multirow{2}{*}{$\begin{array}{l}\text { Temp. } \\
{\left[{ }^{\circ} \mathrm{C}\right]}\end{array}$} & \multirow{2}{*}{$\begin{array}{l}\text { Period } \\
{[\mathrm{h}]}\end{array}$} & \multirow{2}{*}{$\begin{array}{c}\text { Conv. } \\
{[\%]}\end{array}$} & \multirow{2}{*}{$\begin{array}{c}\text { DIPN } \\
\text { yield } \\
{[\%]}\end{array}$} & \multicolumn{7}{|c|}{ Distribution of DIPN [\%] } \\
\hline & & & & & $1,3-$ & $1,4-$ & $1,5-$ & $1,6-$ & $1,7-$ & $2,6-$ & $2,7-$ \\
\hline \multirow[t]{2}{*}{$\operatorname{HM}(25)$} & 240 & 2 & 35.6 & 5.7 & 7.3 & 5.1 & 3.3 & 4.8 & 3.8 & 51.7 & 24.0 \\
\hline & 240 & 8 & 68.3 & 18.4 & 5.3 & 3.8 & 1.9 & 7.1 & 6.1 & 50.8 & 24.9 \\
\hline \multirow[t]{4}{*}{ HY(7) } & 240 & 2 & 94.8 & 43.9 & 32.3 & 14.4 & 8.2 & 14.7 & 13.5 & 8.5 & 8.4 \\
\hline & 240 & 8 & 96.1 & 47.7 & 23.7 & 0.6 & 0.2 & 6.8 & 4.9 & 32.6 & 31.2 \\
\hline & 160 & 2 & 90.0 & 40.5 & 15.1 & 39.8 & 13.1 & 11.0 & 15.5 & 2.8 & 2.7 \\
\hline & 160 & 8 & 94.8 & 45.4 & 20.0 & 36.0 & 12.7 & 11.6 & 13.0 & 3.3 & 3.4 \\
\hline \multirow[t]{4}{*}{ HL(6) } & 240 & 2 & 92.2 & 42.5 & 23.1 & 32.1 & 10.0 & 11.2 & 16.2 & 3.8 & 3.4 \\
\hline & 240 & 8 & 95.1 & 42.5 & 39.9 & 7.9 & 6.7 & 15.3 & 16.3 & 6.7 & 7.2 \\
\hline & 160 & 2 & 66.6 & 23.5 & 14.4 & 38.0 & 12.4 & 10.1 & 18.6 & 2.9 & 2.7 \\
\hline & 160 & 8 & 88.2 & 39.5 & 16.6 & 40.3 & 11.9 & 9.6 & 15.9 & 3.1 & 2.6 \\
\hline $\mathrm{H}-\mathrm{ZSM}-5(70)$ & 240 & 8 & 1.0 & - & - & - & - & - & - & - & - \\
\hline
\end{tabular}

Reaction conditions: naphthalene, $270 \mathrm{mmol}$; propylene, $520 \mathrm{mmol}$; solvent, undecane, $240 \mathrm{ml}$; catalyst, $7 \mathrm{~g}$. 


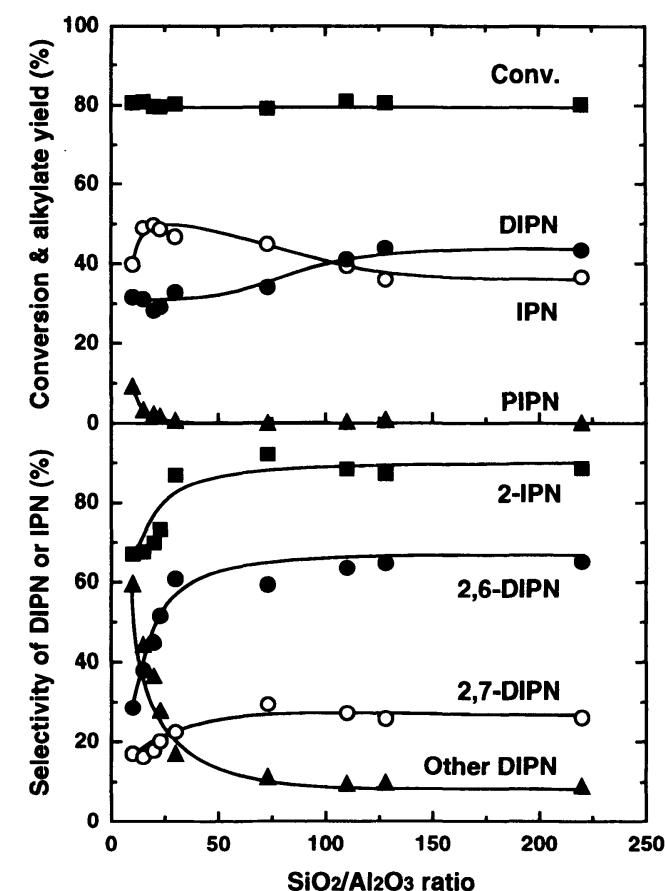

Reaction conditions: naphthalene, $400 \mathrm{mmol} ; \mathrm{HM}, 5 \mathrm{~g}$; propylene pressure, $0.8 \mathrm{MPa}$; temperature, $250^{\circ} \mathrm{C}$.

Fig. 14 Effect of Dealumination on Isopropylation of Naphthalene

の変化はほほ一定となり，2,6-DIPN 選択率はほほ $65 \%$ に達し た。また，ナフタレンが完全に消失した時点における PIPN 中 のテトライソプロピルナフタレン（TIPN）の割合は HM(10) では $30 \%$ であったが, $\mathrm{HM}(220)$ では $2 \%$ 以下であった。 Song らは，2,6-DIPN のイソプロピル化反応を検討し， $\mathrm{SiO}_{2} / \mathrm{Al}_{2} \mathrm{O}_{3}$ 比の低い $\mathrm{HM}$ では外表面における非形状選択的反応 により $\alpha$-置換体を生成するが, この比の高い HM では反応性 が低いことを見い出し，著者らの結果を支持した ${ }^{45) 。 ~}$

脱アルミニウムを行ったHMは，水による被毒を受けにくく なり，2-プロパノールによるビフェニルおよびナフタレンのア ルキル化反応が効率的に進行する77,46),47)。これは, 脱アルミニ ウムにより HM の疎水性が高くなるために, 酸点の耐水性が 向上したことによる。また，プロピレンをアルキル化郕とした 際に, 適量の水を存在させると, 2,6-DIPN 選択率が向上す る ${ }^{48)}$ 。これは, 水の添加により外表面酸点が被毒され, 空孔内 に新しいB 酸点が生成したことによると考えられている。

脱アルミニウムによる HM の触媒挙動の差は炭素質生成と 密接に関係すると考えられ，前に述べたビフェニルのアルキル

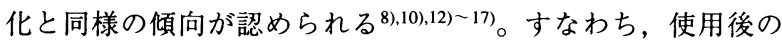
触媒への炭素質析出量は, ビフェニルの場合と同様に, $\mathrm{SiO}_{2} / \mathrm{Al}_{2} \mathrm{O}_{3}$ 比の增加とともに隇少し, $\mathrm{SiO}_{2} / \mathrm{Al}_{2} \mathrm{O}_{3}$ 比 73 以上で は炭素質以外に包接有機化合物が認められた。また, Fig. 15 に示したように HM(10) と HM(220) では, 反応時間と炭素 質生成挙動が全く異なる。すなわち, HM(10) では反応初期 から炭素質が生成するが，HM(220）では反応初期に炭素質生

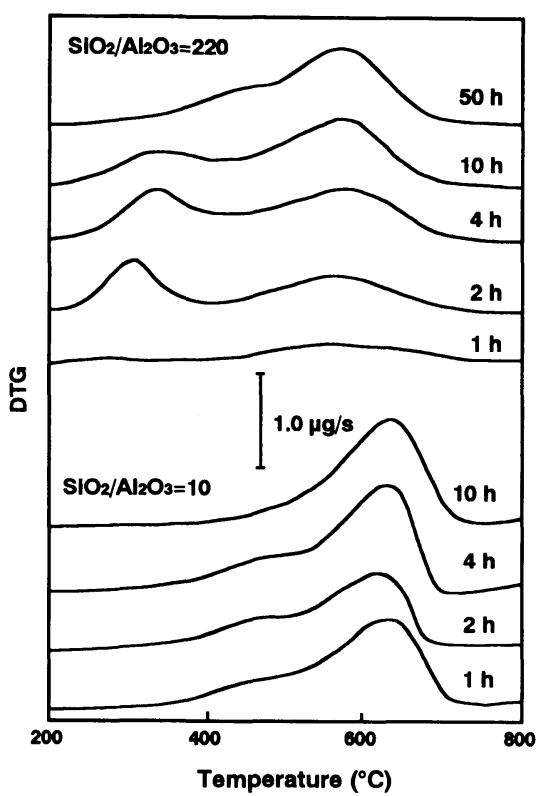

Reaction conditions were the same as in Fig. 14

Fig. 15 Effect of Dealumination of HM on Coke Deposition in Isopropylation of Naphthalene

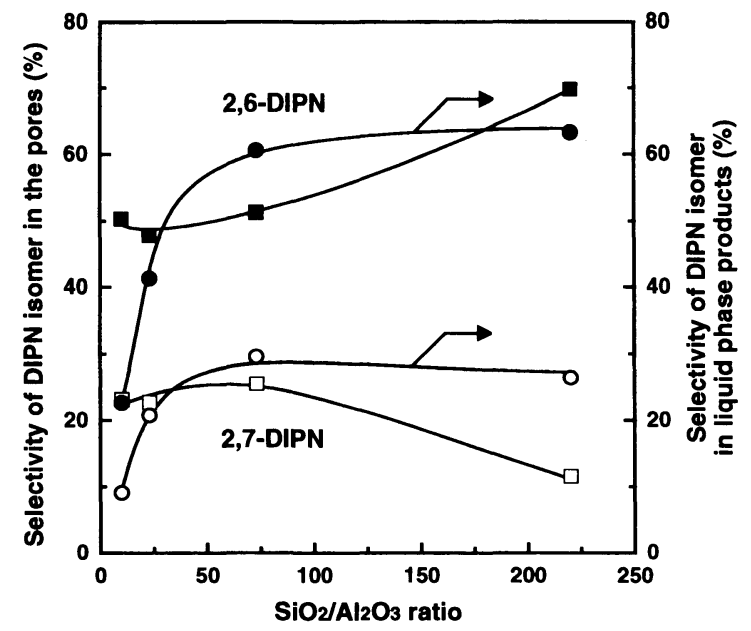

Reaction conditions were the same as in Fig. 14.

Fig. 16 Effect of Dealumination on Product Distribution of Encapsulated 2,6- and 2,7-DIPN inside the Pores and of Bulk Products in Isopropylation of Naphthalene

成速度が低く，また反応が進んでも析出量が低かった。HM （10）の挙動は，急速な炭素質生成に基づく空孔閉そくにより 空孔内反応が不活性化されるために, 主として結晶外表面に生 き残った酸点における非形状選択的反応が起こることと対応し ている。一方, 脱アルミニウムにより酸濃度が減少すると, 炭 素質生成が減少するために, 空孔内における反応が増加し, 形 状選択性が向上する。これらの炭素質生成挙動の差は, 脱アル ミニウムにより酸濃度および酸強度が減少するために, アルキ 


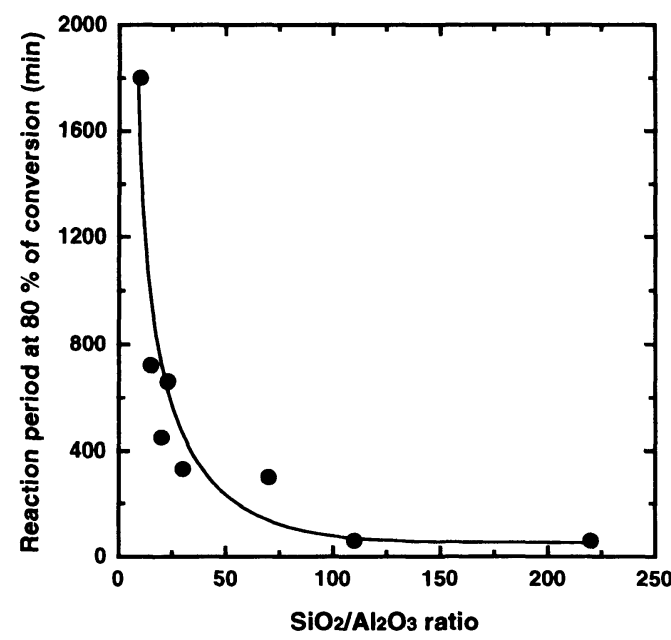

Reaction conditions were the same as in Fig. 14.

Fig. 17 Effect of Dealumination on Catalytic Activity

ル化されたナフタレンからの炭素質生成が抑制されることに基 づくと考えられる。触媒空孔内で起こる反応を明らかにするた めに, これらの触媒に包接されたDIPN 異性体分布を検討した。 Fig. 16 に示したように, 包接 DIPN 異性体中の 2,6-DIPN の選 択率が液相中より高い傾向がみられるので, $\mathrm{SiO}_{2} / \mathrm{Al}_{2} \mathrm{O}_{3}$ 比によ らず空孔内では形状選択的な反応が起こることがわかる。しか し, $\mathrm{SiO}_{2} / \mathrm{Al}_{2} \mathrm{O}_{3}$ 比が低い触媒では, 反応初期に炭素質生成によ り空孔が閉そくされ外表面酸点における反応が優先されるため に，2,6-DIPN 選択率の低下および PIPN の生成が著しくなると 考えられる。なお, $\mathrm{SiO}_{2} / \mathrm{Al}_{2} \mathrm{O}_{3}$ 比 23 以上の $\mathrm{HM}$ では空孔内に おける反応が優先されると考えられる。

ナフタレン反応率が $80 \%$ に達する時間（Fig. 17）および $\mathrm{NH}_{3}$-TPD ピーク温度（Fig. 3）は 2,6-DIPN の選択性と同様に $\mathrm{SiO}_{2} / \mathrm{Al}_{2} \mathrm{O}_{3}$ 比に依存し, 特に 30 以下での変化が大きかった すなわち, $\mathrm{HM}(10)$ のような $\mathrm{SiO}_{2} / \mathrm{Al}_{2} \mathrm{O}_{3}$ 比の低い $\mathrm{HM}$ では, 触媒活性が低く, また反応の進行とともに反応速度が急激に低 下したために，80\%に達するまでに長時間を要した。しかし， 脱アルミニウムにより $\mathrm{SiO}_{2} / \mathrm{Al}_{2} \mathrm{O}_{3}$ 比を高くすると, 酸濃度の 減少にもかかわらず触媒活性は著しく増加した。一方, 酸強度 の指標である $\mathrm{NH}_{3}$-TPD のピーク温度は $\mathrm{SiO}_{2} / \mathrm{Al}_{2} \mathrm{O}_{3}$ 比とともに 低温側にシフトし, 脱アルミニウムにより酸強度が低下するこ とがわかる。これらの事実は, 先に述べた生成物分布および炭 素質生成の変化と対応している。 HM(10) のような酸濃度お よび酸強度の高い HM では, 反応初期に炭素質生成による空 孔閉そくが起こる。このために, 反応は主として外表面に生き 残った酸点において進行することとなり, 触媒活性および形状 選択性の低下が起こると思われる。すなわち, 触媒活性は酸強 度との相関関係が存在するが, 酸濃度との間には直接的な関係 がないと考えられる。

ナフタレンのイソプロピル化においては，HM 空孔内酸点に おける立体的制限により $\alpha$-位への攻撃が抑制されるために形 状選択性が発現することは容易に理解できる。この事情は, ビ フェニルの場合に4-位と 2-または 3-位への攻撃に差があるこ
Table 3 Effect of Cerium Modification of HM on Isopropylation of 2,6-DIPN ${ }^{\mathrm{a})}$ and Cracking of 1,3,5-TIPB ${ }^{\mathrm{b}}$

\begin{tabular}{|c|c|c|c|c|}
\hline \multirow{2}{*}{ Catalyst } & \multicolumn{3}{|c|}{ Yield [\%] } & \multirow{2}{*}{$\begin{array}{c}\text { Conv. } \\
\text { 1,3,5-TIPB } \\
\text { [\%] }\end{array}$} \\
\hline & IPN & DIPN $^{c)}$ & PIPN & \\
\hline $\mathrm{HM}(128)$ & 2.1 & 15.0 & 15.6 & 35.9 \\
\hline $\mathrm{Ce}(30) \mathrm{HM}(128)$ & 1.1 & 5.8 & 1.4 & 0.6 \\
\hline
\end{tabular}

a) temperature, $250^{\circ} \mathrm{C}$, propylene pressure, $0.8 \mathrm{MPa}$; period, 20 h.

b) temperature, $350^{\circ} \mathrm{C}, W / F=3.5 \mathrm{~g} \mathrm{~h} / \mathrm{mol}$.

c) DIPN isomers except 2,6-DIPN.

とと類似している。しかし，立体的にそれほど大きな差がない 2,6- および 2,7-DIPN 両異性体の選択率に差があり，2,6-DIPN の生成が優先される。このことは, 空孔内においてはより立体 的に小さい 2,6-DIPN の生成する遷移状態が 2,7-DIPN からの場 合に比べて有利であることを示すものであり，事実，触媒中に 包接された DIPN 異性体中の 2,6-DIPN 選択率が高かった ${ }^{8)}$ 。 Horsley らは，2,6-DIPN の空孔内でのエネルギー障壁が 2,7DIPN に比べて低いことをシミュレーションにより示し，2,6-

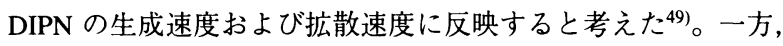
菊地らは，2,6- および 2,7-DIPN 選択性の差が拡散速度の差に 基づく生成物規制が作用するとしている50)。しかし，著者らは， 包接 DIPN 異性体中の 2,6-DIPN 選択率が液相生成物中のもの より高いことから，2,6-/2,7-DIPN 選択性は両異性体の拡散速 度の差によるものでなく，両者を生成する遷移状態における立 体的相互作用による生成速度の差に基づくと考えている ${ }^{8)}$ 。

\section{3. セリウム修飾による表面酸点の制御}

前節で明らかにしたように，脱アルミニウムにより HM の 触媒性能が飛躍的に向上したが，2,6-DIPN 選択率は最高でも $65 \%$ であり，外表面酸点における非形状選択的反応が選択率 を低下させている可能性がある27)。そこで, 外表面酸点の寄与 を明らかにするために, HM 空孔径より大きい分子直径を有す る 1,3,5-TIPB のクラッキング反応を検討したところ， $\mathrm{SiO}_{2} / \mathrm{Al}_{2} \mathrm{O}_{3}$ 比にかかわらず分解活性が高いことがわかった。こ のことは, 高度の脱アルミニウムを行ってもアルキル化反応を 行うのに十分な表面酸点が存在することを示している。2,6DIPN 選択率をさらに向上させるためには，表面酸点を不活性 化し，空孔内における反応の割合を向上させる必要がある。表 面酸点の不活性化には非酸性酸化物による修飾が有効であると 考えられるので, 画性酸化物であるセリアによる表面修飾を検 討した27)。外表面酸点の不活性化を実証する目的で，かさ高い 1,3,5-TIPB のクラッキングおよび 2,6-DIPN のイソプロピル化 反応を検討した（Table 3）。HM(128）で高い 1,3,5-TIPB のク ラッキング活性はセリウム修飾により抑制された。また， 2,6DIPN のイソプロピル化反応においては, HM(128) を触媒と すると 2,6-DIPN の異性化生成物およびアルキル化された PIPN を生成するが，これらはセリウム修飾により著しく減少した。 以上の反応は主として外表面酸点で進行すると考えられるの で，外表面酸点がセリウム修飾により効率的に不活性化された ことがわかる。ナフタレンのイソプロピル化におけるセリウム の修飾効果を Fig. 18 に示した。セリウム修飾により活性の低 


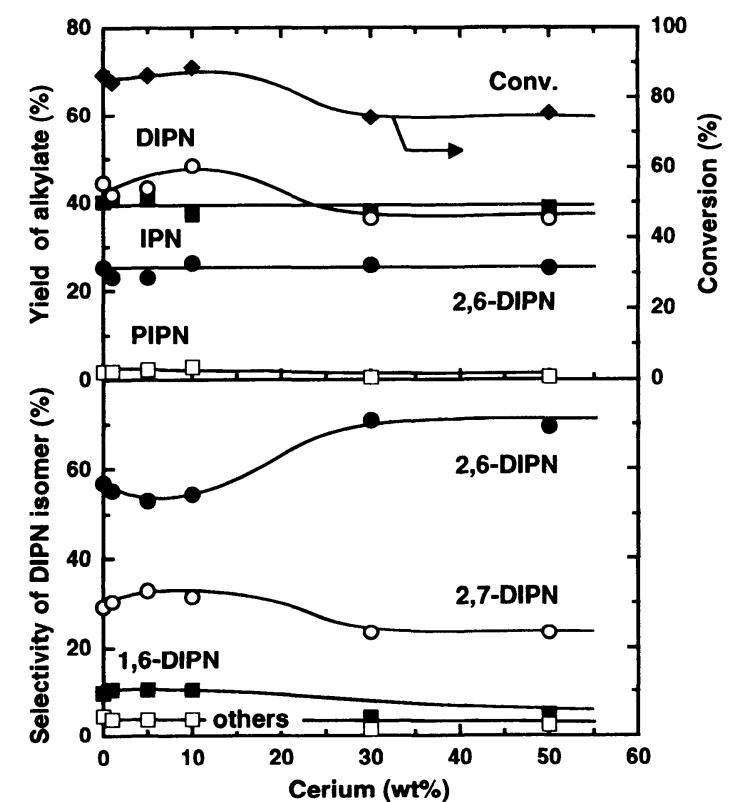

Reaction conditions: catalyst, $1 \mathrm{~g}$; naphthalene, $200 \mathrm{mmol}$; propylene pressure, $0.8 \mathrm{MPa}$; temperature, $300^{\circ} \mathrm{C}$; period, $4 \mathrm{~h}$.

Fig. 18 Effect of Cerium on Isopropylation of Naphthalene over HM(128)

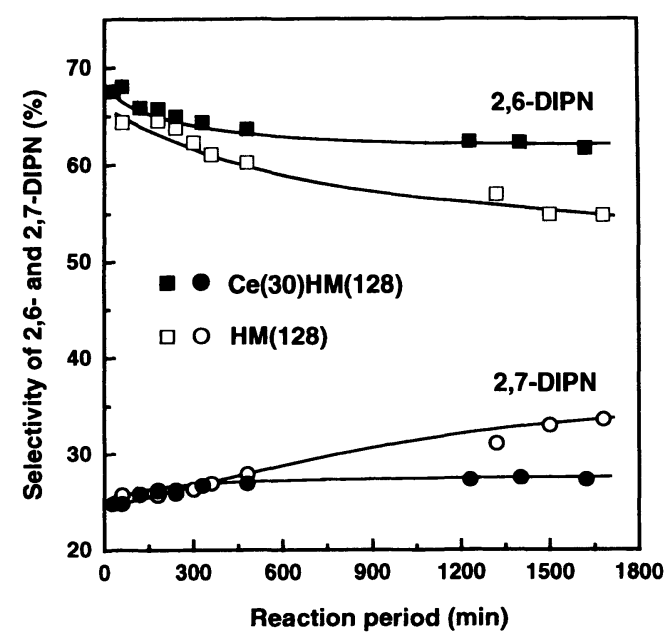

Reaction conditions: catalyst, $5 \mathrm{~g}$; naphthalene, $400 \mathrm{mmol}$; propylene, $0.8 \mathrm{MPa}$; temperature, $250^{\circ} \mathrm{C}$.

Fig. 19 Change in the Selectivity of 2,6-DIPN in Isopropylation over $\mathrm{HM}(128)$ and $\mathrm{Ce}(30) \mathrm{HM}(128)$ Catalysts

下を伴わずに 2,6-DIPN 選択率が向上し，セリウムを $30 \%$ 担持 した $\mathrm{Ce}(30) \mathrm{HM}$ (128) では 70\% に達した。また, Fig. 19 に示 したように，セリウム修飾により反応中の 2,6-DIPN 選択率の 低下が抑制され， $\mathrm{Ce}(30) \mathrm{HM}$ (128) では反応中ほぼ一定であっ た。以上の 2,6-DIPN 選択率の向上は, 外表面酸点の不活性化 による非選択的アルキル化および異性化反応の抑制に基づくも のであると考えられる。なお，七リウムの修飾による表面酸点

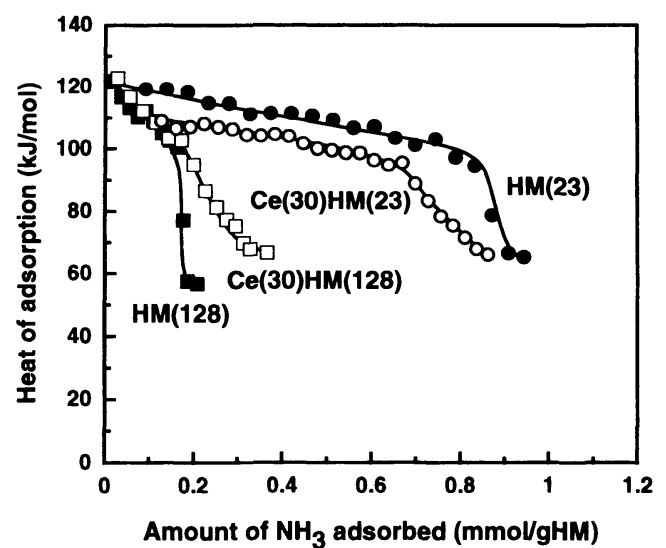

Fig. 20 Heat of Adsorption for Ammonia on Cerium Modified H-Mordenite

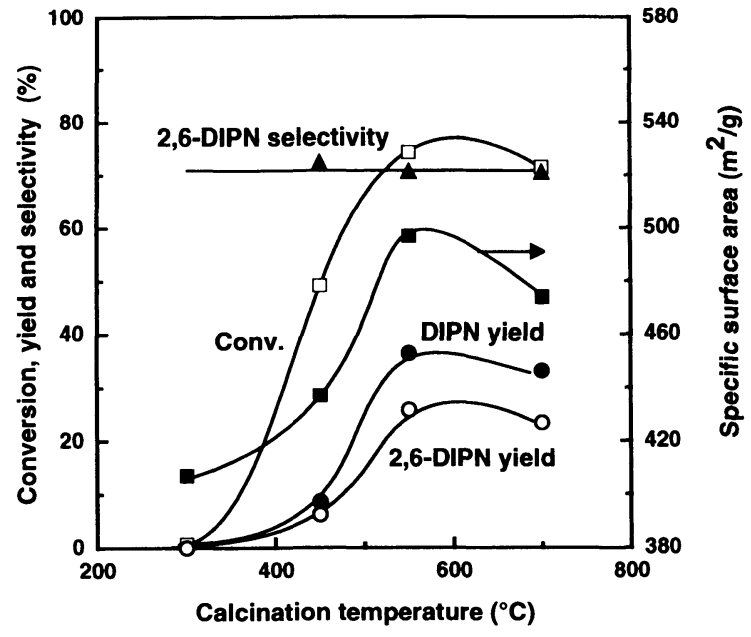

Reaction conditions: catalyst, $1 \mathrm{~g}$; naphthalene, $200 \mathrm{mmol}$; propylene, $0.8 \mathrm{MPa}$; temperature, $300^{\circ} \mathrm{C}$; period, $4 \mathrm{~h}$.

Fig. 21 Effect of Calcination Temperature of $\mathrm{Ce}(30) \mathrm{HM}(128)$ on Isopropylation and on Specific Surface Area

の不活性化効果はビフェニルのイソプロピル化においても確認 され，4,4'-DIPB の異性化による選択率の低下が起こる $300^{\circ} \mathrm{C}$ のような高温および低プロピレン圧においても高い選択率で 4,4’-DIPB が生成した28)。

セリウム修飾による HM の酸的性質の変化を調べるために, アンモニアの吸着熱を検討した ${ }^{27}$ 。Fig. 20 に示したように, $\mathrm{HM}$ (128) ではセリアの担持により $100 \mathrm{~kJ} / \mathrm{mol}$ 以上の強酸点量 の変化は認められなかったが, $\operatorname{HM}(23)$ では多少減少した。 これらの事実は，七リア修飾による新規な酸点生成は少ないこ とを示している。また, セリウム修飾による有効空孔径の変化 を調べるために, ナフタレンの吸着量を測定した。HM(128) および $\mathrm{Ce}(30) \mathrm{HM}(128)$ の室温, 24 時間後の吸着量はそれぞ れ $49.8 \mathrm{mg} / \mathrm{g}$-cat および $50.1 \mathrm{mg} / \mathrm{g}$-cat であり, 修飾による有効 空孔径の変化は少ないものと考えられる。なお, 同様の方法で 調製した La(30)HM(128) はナフタレンを吸着しないことから, 
これらの現象はセリウムに特徽的なものであると思われる。

Fig. 21 に Ce (30) HM(128) の焼成温度がナフタレンのイン プロピル化反応に与える影響を示した ${ }^{27)}$ 。硝酸セリウムの分解 は $200^{\circ} \mathrm{C}$ 近辺で起こるので, $300^{\circ} \mathrm{C}$ 以上ではセリウムはセリア として存在すると考えられるが, $300^{\circ} \mathrm{C}$ 焼成では触媒活性が低 かった。 $550^{\circ} \mathrm{C}$ 焼成時に触媒活性が最高になり，700 $\mathrm{C}$ では低 下した。この際，2,6-DIPN の選択率は焼成温度によらず一定 であった。セリウム修飾 HM の電子顕微鏡観察によると， $550^{\circ} \mathrm{C}$ ではゼオライト結晶がはっきり観測できるのでセリアは 均一に分布しているが, $750^{\circ} \mathrm{C}$ ではセリアが表面に集まり露出 したゼオライト結晶が減少した。また，これらに対応する各元 素の表面分布を検討したところ， $550^{\circ} \mathrm{C}$ では $\mathrm{HM}$ に基づくシリ カおよびアルミナが観測されるが， $700^{\circ} \mathrm{C}$ ではこれらの元素が 隇少し,セリアは表面でシンタリングしていることがわかった。 以上の事実は，セリウム修飾 $\mathrm{HM}$ を $550^{\circ} \mathrm{C}$ 程度で焼成した場 合，セリアが空孔の閉そくなしに外表面に担持されていること

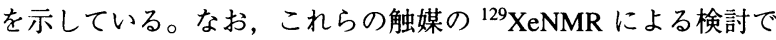
は，セリアは外表面に存在し，空孔内には存在しないことが明 らかになった27)。

ゼオライト外表面の不活性化に関しては, いくつかの報告が なされている。菊地らは，HM 空孔内に進入できないリン酸卜 リブチルで修飾することにより外表面酸点が不活性化でき，ビ フェニルのイソプロピル化に扔いて 4,4'-DIPB の異性化が抑制 できることを報告した ${ }^{51,52)}$ 。一方，Moreau らは，オルトケイ 酸エチルを CVD 法により修飾することによりナフタレンのイ ソプロピル化において $\alpha$-置換体生成の抑制が可能であること を示した ${ }^{53)}$ 。また, Song らは, 反応系に適当量の水を存在さ せることにより，外表面酸点が抑制できることを見い出してい $ろ^{47)}$ 。

\section{7. まとめ}

ビフェニルおよびナフタレンのアルキル化における HM に よる形状選択性に関し，著者らの研究を中心にまとめた。これ らの芳香族化合物の分子直径と似た空孔を有するいくつかの 12 員環ゼオライト（HM，HY，HL）において，その構造によ り形状選択性が発現する場合としない場合がある。この中で特 に, 最も空孔径が小さくかつ一次元構造を有する HM で形状 選択性が発現する。この形状選択性は単なる空孔への出入りに よって発現するのでなく，狭い空孔で基質から生成物（各種異 性体）への遷移状態が立体規制を受けた結果発現することが明 らかになった。

$\mathrm{SiO}_{2} / \mathrm{Al}_{2} \mathrm{O}_{3}$ 比の低い $\mathrm{HM}$ では, コーク生成により短時間で空 孔が閉そくされるために，結晶外表面に生き残った酸点におけ る非形状選択的反応が主として起こる。しかし，脱アルミニウ ムにより HM の触媒活性および選択性が飛躍的に向上した。 脱アルミニウムにより酸点が隇少するにもかかわらず触媒機能 が向上するのは，コーク生成が抑制されることによるものであ る。

ビフェニルのアルキル化ではアルキル化剂の大きさにより形 状選択性の発現が異なる。すなわち，イソプロピル化では， 4,4'-DIPB の生成が選択的であり，かつ高プロピレン圧下でも 4,4'-DIPB のアルキル化がほとんど起こらない。一方，エチル
化では，4,4'-DEBP の選択率が低く，また DEBP 異性体のうち 最もエチル化を受けやすい。以上の差は空孔内における立体的 規制の差に基づくものである。

脱アルミニウムにより HM の表面酸点を隇少させても外表 面の触媒機能は残るが，これらの酸点はセリウム修飾すること により空孔の閉そくなしに不活性化させることができた。以上 のセリウム修飾法はゼオライトの効率的な表面酸点不活性化法 として広く応用されることが期待される。

以上，述べてきたように，脱アルミニウムした HM はその 酸点が非常に少ないにもかかわらずビフェニルおよびナフタレ ンのアルキル化に高い活性を有した。これらの事実は，反応に 関与する酸点は非常に少ないことを示している。また，脱アル ミニゥムにより，結晶の乱れが生じると考えられるにもかかわ らず，空孔が反応場となることは非常に興味ある事実であり， HM の高いポテンシャルを示すものである。脱アルミニウム H-モルデナイトのように活性・選択性に優れた形状選択性触 媒は, 資源の有効利用, 省エネルギーが可能になり, 環境調和 性に優れていると考えられる。今後, 新規のミクロポーラス結 晶および触媒反応の出現を期待したい。

\section{謝 辞}

本研究の一部は新エネルギー産業技術総合開発機構「独創的 産業技術研究開発促進事業」のもとで行われた。ゼオライトを 提供頂いた東ソー (株), 本研究に参加された松崎武彦博士（物 質工学工業技術研究所), 竹内玄樹博士 (新日鐵化学(株)), 松 本勝氏 (大阪ガス (株)), 屠新林博士（当時大阪ガス(株), 現 東亜合成 (株)），金鍾鎬博士（当時物質工学工業技術研究所, 現全南大学), 所卓爾氏 (当時東京理科大学, 現ダイセル化学 工業(株)), 寉田好浩博士（岐皁大学）各氏に感謝いたします。 また，触媒物性の測定に協力頂いた八嶋建明教授（東京工業大 学), 加藤明博士（(株) 日立製作所), 中田真一博士 (千代田化 工建設 (株))，G. Seo 教授（全南大学）およびC. Park教授 (Korean Advanced Inst. of Science \& Technology) に深く感謝し ます。

\section{References}

1) Venuto, P. B., Micropor. Mater., 2, 297 (1994)

2) Csicsery, S. M., Zeolite, 4, 202 (1984)

3) Weitkamp, J., Ernst, S., Catal. Today, 19, 107 (1994)

4) Sugi, Y., Toba, M., Catal. Today, 19, 187 (1994).

5) Namba, S., Shokubai, 37, 606 (1995)

6) Sugi, Y., Kubota, Y., "Catalysis vol.13," Royal Soc. Chem., (1997), p. 55-84

7) Sugi, Y., Matsuzaki, T., Tokoro, T., Hanaoka, T., Takeuchi, K., Tu, X., Takeuchi, G., Sekiyu Gakkaishi, 37, (4), 376 (1994).

8) Kim, J.-H., Matsuzaki, T., Hanaoka, T., Kubota, Y., Sugi, Y., Matsumoto, M., Tu, X., Micropor. Mater., 5, 113 (1995).

9) Matsuzaki, T., Sugi, Y., Hanaoka, T., Takeuchi, K., Arakawa, H., Tokoro, T., Takeuchi, G., Chem. Express, 4, 413 (1989).

10) Sugi, Y., Matsuzaki, T., Hanaoka, T., Takeuchi, K., Tokoro, T., Takeuchi, G., Stud. Surf. Sci. Catal., 60, 303 (1991).

11) Takeuchi, G., Okazaki, H., Kifuji, T., Sugi, Y., Matsuzaki, T., Sekiyu Gakkaishi, 34, (3), 242 (1991).

12) Sugi, Y., Matsuzaki, T., Hanaoka, T., Kubota, Y., Kim, J.H., Tu, X., Matsumoto, M., Catal. Lett., 26, 181 (1994). 
13) Sugi, Y., Matsuzaki, T., Hanaoka, T., Kubota, Y., Kim, J.H., Tu, X., Matsumoto, M., Catal. Lett., 27, 315 (1994).

14) Sugi, Y., Matsuzaki, T., Hanaoka, T., Kubota, Y., Kim, J.H., Tu, X., Matsumoto, M., Stud. Surf. Sci. Catal., 90, 391 (1994).

15) Sugi, Y., Xu, T., Matsuzaki, T., Hanaoka, T., Kubota, Y., Kim, J.-H., Matsumoto, M., Igarashi, A., Shokubai, 37, 152 (1995)

16) Hanaoka, T., Nakajima, K., Sugi, Y., Matsuzaki, T., Kubota, Y., Igarashi, A., Kunimori, K., Catal. Lett., 50, (3-4), 149 (1998).

17) Nakajima, K., Hanaoka, T., Sugi, Y., Matsuzaki, T., Kubota, Y., Igarashi, A., Kunimori, K., Preprints ACS Div. Petro. Chem., in press.

18) Sugi, Y., Matsuzaki, T., Hanaoka, T., Kubota, Y., Kim, J.-H., Tu, X., Matsumoto, M., Sekiyu Gakkaishi, 37, (5), 557 (1994).

19) Tu, X., Matsumoto, M., Matsuzaki, T., Hanaoka, T., Kubota, Y., Sugi, Y., Catal. Lett., 21, 71 (1993).

20) Sugi, Y., Tu, X., Matsuzaki, T., Hanaoka, T., Kubota, Y., Kim, J.-H., Matsumoto, M., Nakajima, K., Igarashi, A., Catal. Today, 31, 3 (1996).

21) Tu, X., Matsumoto, M., Maeda, T., Sugi, Y., Matsuzaki, T., Kubota, Y., Kim, J.-H., "Advanced Materials '93, II/A Biomaterials, Organic and Intelligent Materials," eds. by Aoki, H., Segawa, K., Nishi, T., Hasegawa, M., Karube, I., Kitajima, T., Takahashi, K., Elsevier, Amsterdam (1994), p. 157.

22) Tu, X., Matsumoto, M., Maeda, T., Sugi, Y., Matsuzaki, T., Hanaoka, T., Kubota, Y., Kim, J.-H., Micropor. Mater., 3, 593 (1995).

23) Matsumoto, M., Tu, X., Sugi, Y., Matsuzaki, T., Hanaoka T., Kubota, Y., Kim, J.-H., Nakajima, K., Igarashi, A. Kunimori, K., Stud. Surf. Sci. Catal., 105, 1317 (1997).

24) Nakajima, K., Hanaoka, T., Sugi, Y., Matsuzaki, T., Kubota, Y., Kunimori, K., Preprints ACS Div. Petro. Chem., in press.

25) Kim, J.-H., Matsuzaki, T., Takeuchi, K., Hanaoka, T. Kubota, Y., Sugi, Y., Tu, X., Matsumoto, M., "Advanced Materials '93, II/A: Biomaterials, Organic and Intelligent Materials," eds. by Aoki, H., Segawa, K., Nishi, T., Hasegawa, M., Karube, I., Kitajima, T., Takahashi, K., Elsevier, Amsterdam (1994), p. 153.

26) Sugi, Y., Kim, J.-H., Matsuzaki, T., Hanaoka, T., Kubota, Y., Tu, X., Matsumoto, M., Stud. Surf. Sci. Catal., 84, 1837 (1994).

27) Kim, J.-H., Sugi, Y., Matsuzaki, T., Hanaoka, T., Kubota, Y.,
Tu, X., Matsumoto, M., Kato, A., Seo, G., Pak, C., Appl. Catal., A: General, 131, 15 (1995).

28) Nakajima, K., Hanaoka, T., Matsuzaki, T., Tawada, S., Kubota, Y., Sugi, Y., Kunimori, K., in preparation.

29) Weisz, P. B., Filette, J. J., Maatman, R. W., Mower, E. B., J. Catal., 1, 307 (1962).

30) Young, L. B., Butter, S. A., Kaeding, W. W., J. Catal., 76, $418(1982)$

31) Kim, J.-H., Namba, S., Yashima, T., Appl. Catal., A, 83, 51 (1992).

32) Csicsery, S. M., J. Catal., 19, 394 (1970); 23, 124 (1971).

33) Kim, J.-H., Namba, S., Yashima, T., Zeolites, 11, 59 (1991).

34) Toba, M., Katayama, A., Mizukami, F., Niwa, S., Sano, Y., Maeda, K., Shokubai, 32, 392 (1990).

35) Dejaifve, P., Auroux, A., Gravelle, P. C., Vedrine, J. C., Gabelica, Z., Derouane, E., J. Catal., 70, 123 (1981).

36) Guisnet, M., Magnoux, P., Appl. Catal., 54, 1 (1989)

37) Bhatia, S., Beltramini, J., Do, D. D., Catal. Rev. Sci. Eng., 31, 431 (1989-90).

38) Sawa, M., Niwa, M., Murakami, Y., Appl. Catal., 53, 169 (1989), and their earlier papers cited in.

39) Karge, H. G., Weitkamp, J., Chem. Ind. Tech., 58, 946 (1986).

40) Lee, G. S., Maj, J. J., Rocke, S. C., Garces, J. M., Catal. Lett., 2, 243 (1989)

41) Derouane, E. G., Gabelica, Z. J., Catal., 65, 486 (1980).

42) Sakamoto, N., Takai, T., Taniguchi, T., Takahata, K. (Mitsui Petr. Chem.), Jpn. Tokkyo Kokai, 63-122 635 (1988).

43) Fellmann, J., Catalytica Highlights, 17, (1), 1 (1991)

44) Katayama, A., Toba, M., Takeuchi, G., Mizukami, F., Niwa, S., Mitamura, S., J. Chem. Soc., Chem. Commun., 39 (1991).

45) Schmitz, A. D., Song, C., Catal. Today, 31, 19 (1996).

46) Song, C., Kirby, S., Micropor. Mater., 2, 467 (1994).

47) Chu, S.-J., Chen, Y.-W., Ind. Eng. Chem. Res., 33, 3112 (1994).

48) Schmitz, A. D., Song, C., Catal. Lett., 40, 59 (1996).

49) Horsley, J. A., Fellmann, J. D., Derouane, E. G., Freeman, C. M., J. Catal., 147, 231 (1994).

50) Kikuchi, E., Sawada, K., Maeda, M., Matsuda, T., Stud. Surf. Sci. Catal., 90, 391 (1994).

51) Matsuda, T., Kikuchi, E., Stud. Surf. Sci. Catal., 83, 295 (1994).

52) Matsuda, T., Urata, T., Saito, U., Kikuchi, E., Appl. Catal., 131, 215 (1995)

53) Moreau, P., Finiels, A., Geneste, P., Moreau, F., Solofo, J., J. Catal., 136, 487 (1992). 


\title{
Shape-selective Alkylation of Polynuclear Aromatic Hydrocarbons over H-Mordenites
}

\author{
Yoshihiro SUGI $^{\dagger 1)}$ and Takamasa HANAOKA ${ }^{\dagger 2)}$ \\ †1) Dept. of Chemistry, Faculty of Engineering, Gifu University, 1-1 Yanagido, Gifu 501-1193 \\ ${ }^{\dagger 2)}$ National Institute of Materials and Chemical Research, 1-1 Higashi, Tsukuba, Ibaraki 305-8565
}

Liquid phase alkylation of polynuclear aromatic hydrocarbons, such as biphenyl and naphthalene, over $\mathrm{H}$ mordenite (HM) was studied. Selective formation of the narrowest products, 4,4'-diisopropylbiphenyl (4,4'-DIPB) and 2,6-diisopropylnaphthalene (2,6-DIPN) occurred only over HM among the zeolites with twelve-membered pore openings. These shape-selective catalysis are ascribed to steric restriction of transition state and to entrance of bulky substrates into the pores. Catalytic activity and shapeselectivity are governed by coke-deposition on the acid sites inside the pores. Dealumination of HM enhanced catalytic activity and the selectivity of 4,4'-DIPB and 2,6-DIPN because of the decrease of coke-deposition, while the activity and the selectivity were low over HM with the low $\mathrm{SiO}_{2} / \mathrm{Al}_{2} \mathrm{O}_{3}$ ratio. Non-regioselective catalysis occurs on external acid sites because the acid sites inside the pores are deactivated by blocking pores due to severe coke-deposition.

Selectivity of DIPB isomers was changed with propylene pressure. Selective formation of 4,4'-DIPB occurred under high propylene pressure $(<0.3 \mathrm{MPa})$, while the selectivity of 4,4'-DIPB decreased with the conversion under such low propylene pressure as $0.2 \mathrm{MPa}$ because of isomerization of 4,4'-DIPB to $3,4^{\prime}$ '-DIPB. 4,4'-DIPB was almost exclusive isomer in the encapsulated DIPB isomers inside the pores under all pressures. Preferential adsorption of propylene prevents isomerization of 4,4'-DIPB under high pressures. Isomerization of $4,4^{\prime}$-DIPB occurs on the external acid sites under low pressures.

Selectivity of 4,4'-diethylbiphenyl (4,4'-DEBP) in ethylation of biphenyl was much lower than that in isopropylation. Among the DEBP isomers, 4,4'-DEBP has the highest reactivity for ethylation to higher ethylates inside the pores, whereas isopropylation of 4,4'-DIPB was negligibly low inside the pores. These differences are ascribed to the difference in steric restriction at the transition state composed of substrate, propylene, and acid sites inside the pores.

Deactivation of external acid sites of HM was examined to reduce non-regioselective alkylation and isomerization. External acid sites were deactivated by calcination after impregnation of cerium on $\mathrm{HM}$ without the decrease in pore radii. Selectivities of 2,6-DIPB and 4,4'-DIPB were improved in the isopropylation of naphthalene and biphenyl because of the suppression of non-regioselective alkylation and isomerization at the external surface.

\section{Keywords}

H-Mordenite, Alkylation, Polynuclear aromatics, Biphenyl, Naphthalene, Shape-selectivity 